\title{
PREHISTORIC METAL MINING IN BRITAIN: THE STUDY OF COBBLE STONE MINING TOOLS BASED ON ARTEFACT STUDY, ETHNOGRAPHY AND EXPERIMENTATION*
}

\author{
MINERÍA PREHISTÓRICA EN GRAN BRETANAA: EL ESTUDIO DE \\ HERRAMIENTAS MINERAS LÍTICAS A PARTIR DE ESTUDIOS \\ ARTEFACTUALES, ETNOGRAFÍA Y EXPERIMENTACIÓN
}

\author{
Simon Timberlake ${ }^{1}$ and Brenda Craddock ${ }^{2}$
}

\begin{abstract}
Archaeological fieldwork carried out by the Early Mines Research Group has led to the discovery of 11 Early Bronze Age (2,1501,500 BC) copper mines; nine in Wales and two in England. Together with the workings on the Great Orme, some 12 Bronze Age mines have now been identified. The radiocarbon dates from these mines indicate small-scale mining/prospecting in Western Britain during the 2nd millennium BC, most sites being abandoned by the Middle Bronze Age (1,500-1,100 BC).

The characteristic artefacts of Early Bronze Age metal mining are cobble stone mining tools. Examination of the wear pattern and modifications to these cobbles suggests the creation of ad hoc tool kits and the use of both hand-held and hafted implements. Over $90 \%$ show little or no evidence of modification (such as a pecked groove for hafting), yet from experimentation we know that many were probably used with handles. Discrimination in the collection of cobbles is suggested by consistency in size, shape, weight and lithology of the stones. In West Wales some cobbles were brought $25 \mathrm{~km}$ inland to be used at these upland sites. This paper describes a method of recording, analysing and interpreting these tools which is universally relevant.
\end{abstract}

Key words: Early Bronze Age, Great Britain, oxidised copper ores, mining tools, experimentation.

El trabajo arqueológico de campo realizado en el Reino Unido por el Grupo de Investigación de Minería Temprana ha conducido al descubrimiento de 11 minas de cobre pertenecientes al Bronce Antiguo (2.150-1.500 a.C.), de las cuales nueve se encuentran en Gales y dos en Inglaterra. En el Great Orme han sido identificadas alrededor de 12 minas de la Edad del Bronce. Las fechas de radiocarbono de estas minas en el oeste de Gran Bretaña indican una fase relativamente corta de minería a pequeña escala o, posiblemente, de prospección, la cual ha sido datada a principios del $2^{\circ}$ milenio antes de Cristo. No obstante, la mayoría de los sitios fueron abandonados en el Bronce Medio (1.500-1.100 a.C.).

Los objetos característicos de la primera Edad del Bronce en la minería metálica en instrumentos fabricados a partir de cantos rodados de piedra. El estudio de las huellas de uso y la modificación de las piedras sugiere la creación de conjuntos de herramientas ad-hoc y el uso tanto de martillos de mano como enmangados. Más del $90 \%$ de estas herramientas muestran poca o ninguna evidencia de modificación intencional (p.ej. surco picoteado diseñado para el enmangado), sin embargo, a partir de una amplia experimentación sabemos que muchas de estas herramientas podrían haber sido utilizadas con mangos. Se sugiere algún tipo de selección en la colecta de cantos rodados, a partir de la coherencia en el tamaño, forma, peso y litología de las piedras. Así, en el oeste de Gales algunos cantos fueron trasladados desde la costa a tierra adentro hasta 25 km para ser utilizados en estos sitios de tierras altas. En este trabajo se describe un método de registro, análisis e interpretación de estas herramientas, que es de interés universal.

Palabras claves: bronce Antiguo, Gran Bretaña, minerales oxidados de cobre, herramientas mineras, experimentación.

\section{Bronze Age Metal Mines}

Over the last twenty years the discovery and excavation of some twelve Bronze Age metal mines or prospecting sites, and the probable identification of at least eight others within England and Wales (Figure 1), have provided a suitable timeframe for the first exploitation of metal within the UK (Timberlake 2009). This activity consisted of a widespread phase of early prospection taking place between 2000 and $1650 \mathrm{BC}$ followed by production at a very limited number of sites (such as the Great Orme in North Wales) continuing right up until the Late Bronze Age (1,100-650 BC). All of

\footnotetext{
* Artículo seleccionado del conjunto de ponencias presentadas en la Primera Reunión Internacional sobre Minería Prehispánica en América (PRIMPA), realizada en San Pedro de Atacama, Chile, diciembre 2010. Este manuscrito fue evaluado por investigadores externos y editado por Diego Salazar y Valentina Figueroa, en su calidad de editores invitados de la Revista.

1 Department of Archaeology, University of Cambridge, Cambridge CB2 3DZ UK

2 Early Mines Research Group, c/o 56 St. Margaret's Street, Rochester, Kent ME1 1TU UK. earlyminesresearchgroup.org.uk
} 


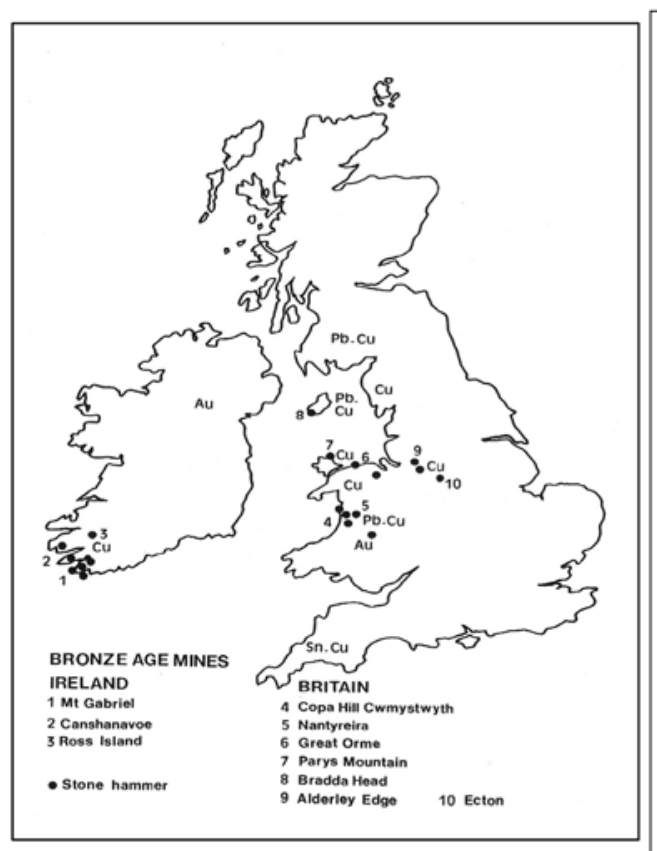

\section{Bronze Age Copper Mines}

Alderley Edge 3470 +/- 90 BP (1920-1640 Cal BC)

Ecton Hill $3445+/-35$ BP (1880-1640 Cal BC)

Parys Mt $3490+/-50$ BP $(1940-1680$ Cal BC) $3600+/-70$ BP $(2140-1740$ Cal BC)

Great Orme $\quad 3290+/-60 \mathrm{BP}(1740-1720 \mathrm{Cal} \mathrm{BC})$ $2450+/-60 \mathrm{BP}(770-440 \mathrm{Cal} \mathrm{BC})$

Nantyreira $\quad 3410+/-50$ BP $(1880-1600$ Cal BC)

Copa Hill $3690+/-90$ BP $(2400-1750$ Cal BC) $2990+/-190$ BP (1700-800 Cal BC)

Erglodd $\quad 3840+/-40$ BP $(2340-2130$ Cal BC)
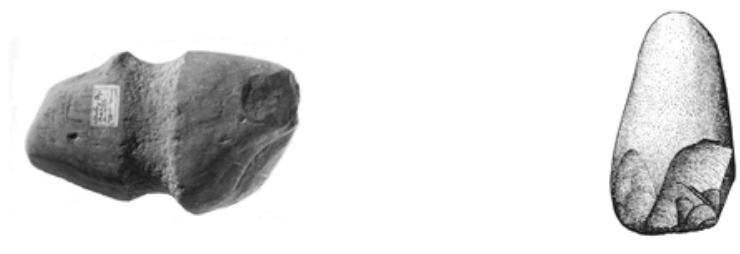

Figure 1. A map of Bronze Age mines and stone mining tools in the British Isles, plus sources of prehistoric metal.

Mapa de las minas de la Edad del Bronce y herramientas mineras en piedra de las Islas Británicas, además de las fuentes de metal prehistóricas.

these investigations, except for that on the Great Orme, form part of a long term programme of study currently being undertaken by the Early Mines Research Group.

\section{Parys Mountain}

Bronze Age workings have been identified at Parys Mountain on the northeastern corner of Anglesey (Timberlake 1990a; Jenkins 1995). 'Primitive' style surface workings mined using stone cobble tools and with brushwood fires were reported in 1796 (Briggs 1976). One small area of this was re-located in the 1930s, and then subsequently re-excavated and dated by the present team in 1988. More recently several prehistoric workings have been discovered and excavated underground by David Jenkins at the points where these drifts intersect with the roofs of nineteenth century levels and stopes at depths of around $5 \mathrm{~m}$ to $50 \mathrm{~m}$ below surface (Figure 2). The form of these deposits seem to suggest the repeated working (or redeposition) of worked mine spoil within a series of steeply inclined opencasts dug on surface weathered portions of quartz stockwork veins associated with the Carreg y ddol and North Discovery Lodes. The access for these seems to be on the underlie of the chalcopyrite veins at points where these could be excavated through the softer and partly decomposed pyritic shales and slates coinciding with areas where the local water table had been lowered due to fracturing and previous solution of the sulphide veins. The rapid oxidation of pyrite following its exposure will have led to the formation of a gossan, most of which will have been removed through glaciation, though in places this would have become partly re-established during the seven millennia leading up to the Bronze Age. Native copper and tenorite (copper oxide) were noted in gossans 'beneath the soil' above some of the virgin copper veins in the $18^{\text {th }} / 19^{\text {th }}$ century (Lentin 1800). It seems likely therefore that the Bronze Age miners could have been extracting these minerals from the surface, and below this perhaps, the copper sulphate minerals such as we find today within the zone of rapidly oxidising 


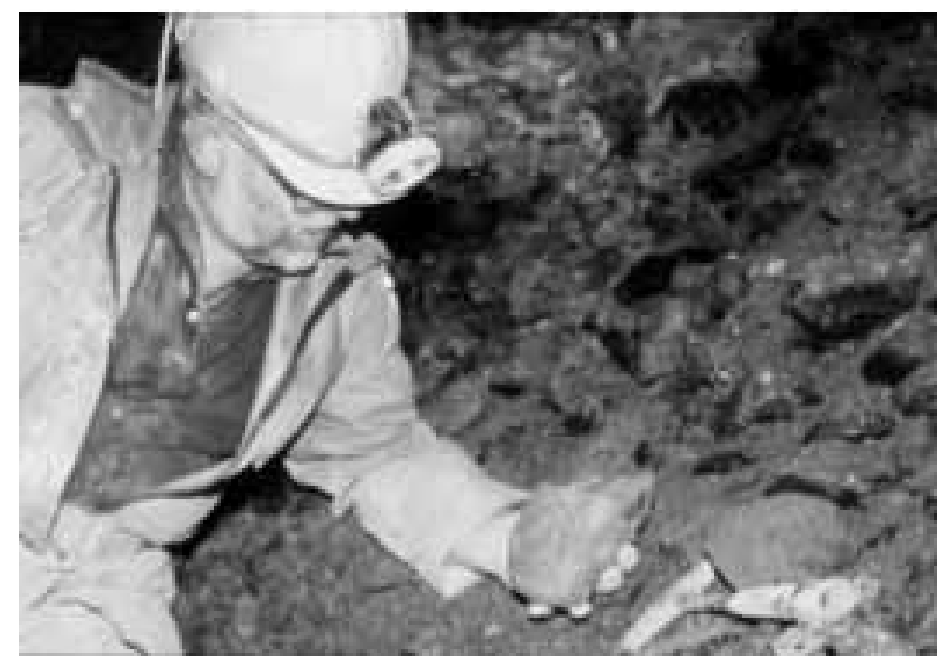

Figure 2. David Jenkins examining stone tools underground on Parys Mountain, Anglesey, Wales.

David Jenkins examinando herramientas de piedra de Parys Mountain, Anglesey, Gales.

sulphide underground. Interestingly, all of these prehistoric workings seem to be associated with the geologically later (remobilised) chalcopyrite, rather than with the primary polymetallic bluestone $(\mathrm{Cu} / \mathrm{Pb} / \mathrm{Zn} / \mathrm{Ag} / \mathrm{As} / \mathrm{Sb})$ ore, supports the notion that it was these simplest suites of oxidised copper minerals which were exploited.

\section{Mid-Wales and Copa Hill, Cwmystwyth}

The largest group of eight Bronze Age mines, the majority of which appear to be little more than prospection sites, is to be found within the Central Wales orefield. Most of these lie within the upland area (more than $100 \mathrm{~m}$ above sea level), though some probable sites are to be found at a lower altitude either side of the Dovey Estuary, and correspond with small, discontinuous, near surface pockets of copper (chalcopyrite) ore on SW-NE trending lead-zinc-silver veins. The majority of these mines seem to be grouped within distinct prospection zones which it is surmised might relate to the rapid tree clearance and erosion which took place during the Early Bronze Age associated with the expansion of transhumance pasture. As a result we may have been seeing the exposure of mineral veins, some of these quartz-ankerite associated with a distinct weathered copper mineralisation, such as the unique occurrence of weathered outcrops of quartz and ankerite vein. We can see this on Copa Hill, Cwmystwyth in the south-east of the orefield, where the Comet
Lode was exploited to remove a rich pocket of ore extracted at surface by means of opencasting to a depth of over 10m (Timberlake 2003).

Artefacts including antler picks and hammers, twisted hazel (withy) ropes and handles for hafted stone tools, basket fragments, mine timber (stemples and cut fire wood), several well preserved wooden launders made of oak and alder used for drainage, and perhaps also for ore washing (split and hollowed out logs up to $5 \mathrm{~m}$ long with the marks of metal tools), and upwards of a thousand cobble stone tools have been recovered from these workings. A mineralogical study of the ancient mining spoil and worked vein in the mine seems to confirm that a weathered chalcopyrite ore intermixed with galena was being exploited here. Finely crushed grains of goethite within the spoil ( $<3 \mathrm{~mm}$ in diameter) appear to contain unoxidised cores of chalcopyrite, suggesting it was this fraction of the ore that was being sought and crushed, perhaps to release copper in the form of disseminated malachite and copper oxide; minerals that could much more easily be smelted.

Exploitation began with the quarrying of the mineralised scree and exposed cliff circa. 2,100 $\mathrm{BC}$, subsequently opencasting of the vein, reaching a depth of over $10 \mathrm{~m}$ by $1,950 \mathrm{BP}$. Thereafter the upper part of the mine was worked whilst the bottoms became flooded round about 1,800 BC. The growth of the blanket peat on the moorland above guaranteed a constant precipitation. The excavation of a rock cut channel followed by a system of wooden 


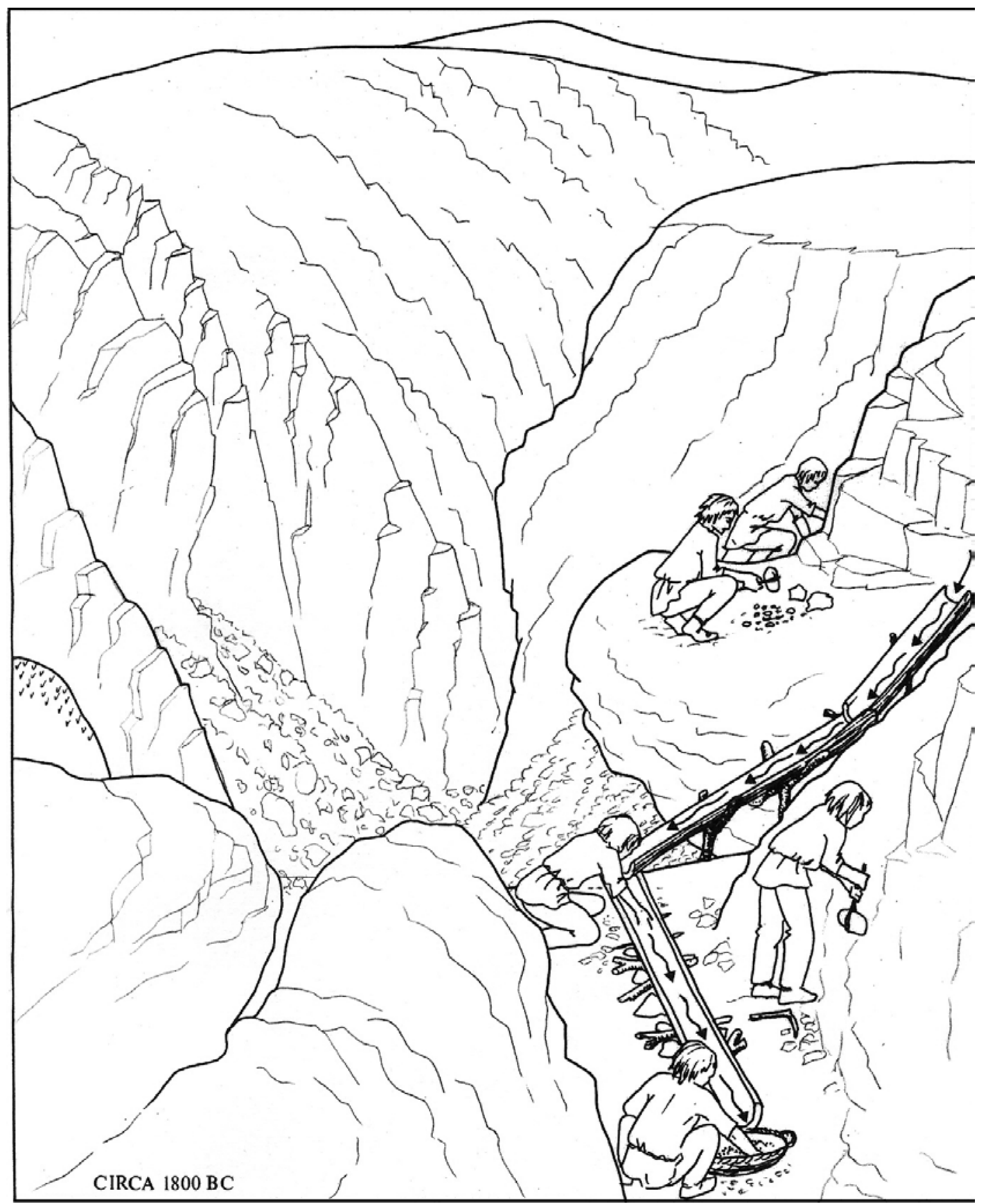

Figure 3. Reconstruction of the use of launders and possible washing process taking place within the Comet Lode Opencast, Copa Hill, Cwmystwyth (ca. 1,800 BC).

Reconstrucción de la utilización de canales y posible lugar de lavado en la explotación a cielo abierto de Comet Lode, Copa Hill, Cwmystwyth (ca. 1.800 a.C.).

launders was adopted as a strategy by the earliest miners to try and tap and divert this incoming water from the top of the mine, yet at the same time this hydrological problem may also have offered them the means by which to wash and gravity separate lead and copper minerals, including the removal of the oxidised copper from the worthless surrounding rock and mineral components (Figure 3). 


\section{Alderley Edge}

In stark contrast to the above geological/ mineralogical setting for early extraction of copper are the Bronze Age mines exploited within the Triassic sandstones of Alderley Edge in Cheshire (Timberlake and Prag 2005). These workings, such as we find at Engine Vein consist of a series of small benched pits connected in places by narrow opencuts dug to extract thin discontinuous lenses of malachite, azurite and occasionally chrysocolla formed between beds of baritised sandstone, conglomerate and mudstone within the Engine Vein Conglomerate (Sherwood Sandstone Group). In fact there are two distinct but related deposits of oxidized copper minerals; one concentrated along the bedding planes of the sandstone which forms richer pockets closer to the mineralising faults, and another copper-poor yet more easily worked deposit consisting of small nodules of malachite and azurite within the intervening mudstone horizons. Both types of beds have acted as barriers, but also as conduits to migrating groundwaters which have carried copper away in solution from the now almost completely oxidized sulphide ores associated with the faults. These dipping cupriferous sandstone beds were traced along their outcrops by means of shallow prospection pits towards the tops of the mineral veins (Figure 4). Prior to the Bronze Age the site may also have been an important source of colourful pigments in the form of yellow pyromorphite, black manganese wad, and of green and blue copper carbonates; something which might be indicated by the presence of Mesolithic hunting camps close to the possible sites of mineral extraction (Timberlake 2009).

\section{Ecton Copper Mines}

Within the last two years several Bronze Age workings have been located on Ecton Hill, a limestone peak on the east side of the Manifold Valley in the Staffordshire, Central England. A prehistoric date for old workings associated with rich 'pipes' of copper ore outcropping on the surface on the hilltop ridge was first suggested following the discovery of a part-worked antler point by the archaeologist John Barnatt during cave exploration undertaken underground at the Stone Quarry (Dutchman) Mine in 1997 (Barnatt and Thomas 1998). Likewise the distribution of hammer stones at surface suggested the presence

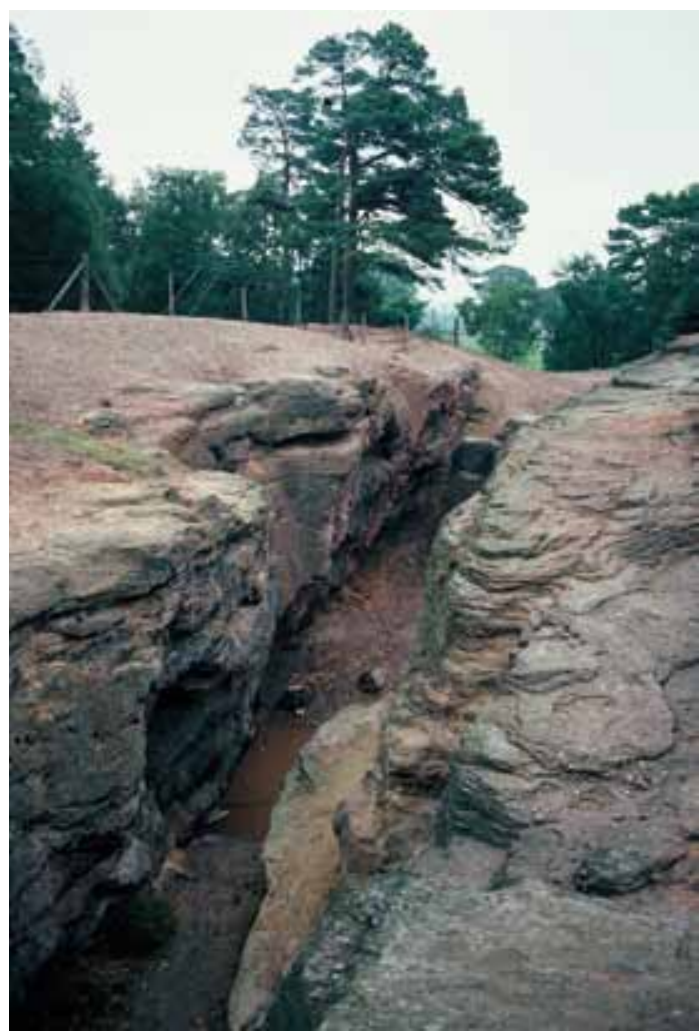

Figure 4. The Engine Vein Opencast at Alderley Edge, Cheshire showing Bronze Age pit workings in section (LH side). La mina a cielo abierto de Engine Vein en Alderley Edge, Cheshire, con explotaciones de la Edad de Bronce (a la izquierda).

of Bronze Age mining at three locations: Ecton Pipe, Stone Quarry, and The Lumb.

The detatchment of the limestone beds within these tightly folded rocks ('saddles') seems to have provided voids for rich pocket mineralisation, and subsequently on exposure, for the development of deep weathering and alteration of the primary chalcopyrite to copper carbonates. The steep dip of the rocks also allowed access of groundwater and the development of minor karst fissures, thereby lowering the water table and still further opening up existing voids which could be enlarged through simple levering and hammering with stone tools.

Less than $500 \mathrm{~m}$ to the south of here, below the summit of the hill, lies the site of another prehistoric mine, The Lumb; these 'lumb' deposits typically consist of E-W fissures containing infills of clay and decomposed limestone. One of these was examined in September 2009. The weathered limestone horizon here was dolomitised and contained secondary mineralisation in the form of vugh 
pockets and veinlets of malachite and goethite. In some ways the working method here was reminiscent of the Great Orme (see Lewis 1996); an outcrop of the copper mineralisation was followed along the strike before being dug down into via a series of worked overhangs over $2 \mathrm{~m}$ deep. These overhangs collapsed, or else were intentionally undermined, as the workings were extended back further, the sites of extraction being small, picked and hammered-out hollows, some of which were found to be associated with splinters of bone and antler tools, and occasionally hand-held hammer stones. Subsequently, the clay-filled fissures above this were opened up in order to gain access via a series of short crawling passages to the top of the dolomite and a number of vertical solution features (palaeokarst or thermokarst), some of which were filled with extractable mineral. A number of these were worked later during the Post-medieval period using firesetting, yet the presence of occasional hammerstone marks attests to the presence of prehistoric miners.

Twelve bone and antler tools from the two sites of prehistoric mining have now been dated. Collectively these provide us with a calibrated date range for the working period of the mine with a start date of between 1,880-1,700 cal BC and an end date of 1,760-1,640 cal BC (as determined by Bayesian analysis). Recent statistical modelling of these bone and antler radiocarbon dates undertaken by the Scientific Dating Team at English Heritage (John Meadows personal communication) suggests a plausible scenario that the Bronze Age working of Stone Quarry Mine was of longer duration than that carried out on The Lumb. In either case, it appears unlikely that mining lasted for more than a few decades at either of these sites.

Field survey at Ecton has shown that over 50\% of the hammerstones used in mining during the Bronze Age are likely to have been procured locally from the bed of the River Manifold, literally from collection sites within view of the mines themselves.

\section{Prehistoric Stone Mining Tools from the UK: A Study Based on Artefact Analysis, Ethnography and Experimentation}

\section{Early discoveries}

The first recorded find of stone mining tools comes from the mine of Twll y mwyn in mid-Wales.
When Lewis Morris re-opened this ancient trench working in 1742 his miners found stone tools and traces of burning. His comments at the time show him to be an astute observer "...the wedges were sea stones, with one end nipped off to an edge, and there is an impression on the other end where they used to strike on them...it seems [to me] the mine was worked before man knew the use of iron..." (Bick and Davies 1994). Sir Christopher Sykes when visiting the great opencast working on Parys Mountain also considered the tools he saw as dating to a time "..before Iron was used in this Kingdom" (Sykes 1796). Stone mining tools were found at Cwmystwyth in 1813 (Davies 1815), at the Great Orme and Parys Mountain in 1850 (Stanley 1850, 1873), and at the copper mines of Ecton, Staffordshire, England in 1855 (Bateman 1855; Pickin 1999). In 1874 William Boyd-Dawkins investigated the discovery of grooved stone tools found within ancient pit workings at Brynlow Mine on Alderley Edge which he described "..as perhaps belonging to the Bronze Age, when the necessary copper was eagerly being sought throughout the whole of Europe", comparing these tools to the Egyptian ones he had seen from the Sinai (Dawkins 1875).

A rather more broad-ranging study of stone tools and primitive mining in Britain was undertaken by Oliver Davies for the British Association for the Advancement of Science in the 1930s (Davies 1935, 1936). Davies investigated Cwmystwyth, Great Orme, Parys Mountain and Nantyreira mines in Wales, digging small trenches within the mine tips (Davies 1938, 1939, 1947). Unable to date the charcoal, and with no pottery or artefacts, he referred to all of these mines simply as being "..Roman or old Celtic in age". He concluded that the cobbles were either 'pounding stones' or 'anvil-querns', but erroneously considered them to have been "..broken to give better grip" (Davies 1947).

\section{Recent studies}

Our first modern study of these artefacts was undertaken by John Pickin in 1989/90. His typology consisted of 6 classes of cobble tools: unmodified (Type 1), surface-pecked (Type 2 a-d), edge-notched (Type $3 \mathrm{a}-\mathrm{b}$ ), partially grooved (Type $4 \mathrm{a}-\mathrm{b}$ ), singlegrooved (Type 5) and multiple-grooved (Type 6 a-d) (Pickin 1990). As a very simple classification of modified tools, this typology still stands. Around 
the same time David Gale was undertaking work for his $\mathrm{PhD}$ at Bradford University. This was a functional study of stone tools that examined both their use-wear and also cobble morphometry (Gale 1995). Although a comprehensive piece of work, this preceded many of the archaeological excavations and involved no experimental/ reconstructions of tools.

\section{Survival of stone tools}

The distribution of known occurrences of this type of cobble stone hammer at or near to mining sites in the British Isles correlates with some (but not all) of the areas of near-surface copper deposits, particularly along the west coast of Britain (see Figure 1). Recent fieldwork suggests good survival of tools at mine sites, even where these have become dispersed as a result of redeposition by later mining. By and large this comes down to skill in recognition.

All of the archaeologically excavated sites associated with in situ finds of cobble stone hammers have proved to be Bronze Age (or at the very latest Early Iron Age), despite the assertions of some sceptics that these tools, therefore the mines, may have been Medieval, even modern, perhaps worked by poverty-stricken miners (Briggs 1983, 1988, 1993). Even so, fully grooved hammer stones, which elsewhere are more commonly accepted as being prehistoric mining tools are rare in Britain; in fact within the British Isles these grooved hammers are only found at Ross Island, Killarney, Eire (O'Brien 2004) and at Alderley Edge in Cheshire, England (Timberlake 2005a). There are none from Wales. The much greater number of unmodified, or almost unmodified cobble tools at these Bronze Age mines may help to explain why so many of these sites went unrecognised, at least up until the onset of more systematic fieldwork during the last two decades.

The presence of splinters/ flakes alongside larger fragments of hammer within mine spoil layers indicates where prehistoric mining was well localised. In fact this is a very good test of the in situ status of stone mining tools in cases where one might be attempting to date such mining contexts both above and below ground. Invariably these tools are normally found broken up and re-used, either within ancient surface spoil, as purposeful backfill underground, or as spoil slumped down from the surface into shallow underground workings.
Hammer stones, or fragments of hammer stones, are more or less indestructible, surviving any amount of later reworking. In most cases the fragments of these tools never disperse far from source, even when redeposited several times. Experience has shown that if a range of these can be found, then the approximate site(s) of prehistoric mining can usually be identified.

\section{Terminology}

A word or two should be said about the terminology of these tools. Most of us interested in the study of ancient mining will be aware that stone mining tools are both rudimentary and universal-by and large these tend to be quite similar in form and a product of utilitarian need rather cultural design. Given their universal nature it is perhaps surprising why there is no so little standardisation in functional analysis and terminology. These tools (some of them with quite specific functions) are variously described in the literature as stone mining mauls, hammer stones, stone hammers, stone mallets, pounders, crushing stones, stone picks etc.-often with little or no clear knowledge of function. In order to refer to these in a more appropriate and relevant way it is proposed that these assemblages of stone tools are described using the generic and collective term 'cobble stone mining tools', a term which more accurately reflects their origin as waterworn cobbles (or sometimes rounded weathered lumps of rock) selected for a range of interchangeable mining tool tasks. Only in one sense are all of these tools artefacts: all show some signs of having been used, though very few have actually been intentionally artefacted.

\section{Methodology of recording}

The tasks of object recording/illustration, functional analysis and experiment are closely linked in the process we have adopted for interpreting the use and significance of these stone mining toolsets. Dealing with thousands of cobble stone mining tools we have found it absolutely essential to develop some sort of simply analytical, yet quite standardised method of recording that can easily be undertaken in the field. One of the most important tasks in recording is accurate illustration. Figure 5a shows the type of annotated and measured field drawing which can be produced fairly quickly whilst recording large numbers of hammer stones 
$\mathrm{CH} 89$

$1.475 \mathrm{KG}$

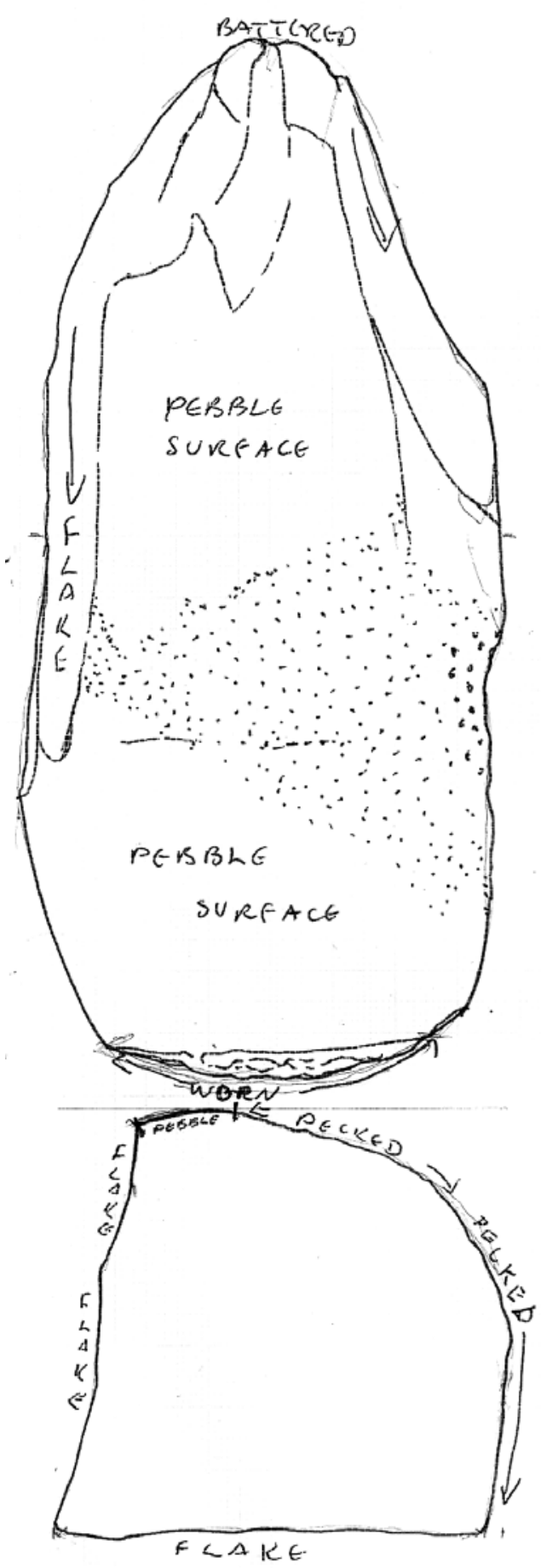

DRAWN

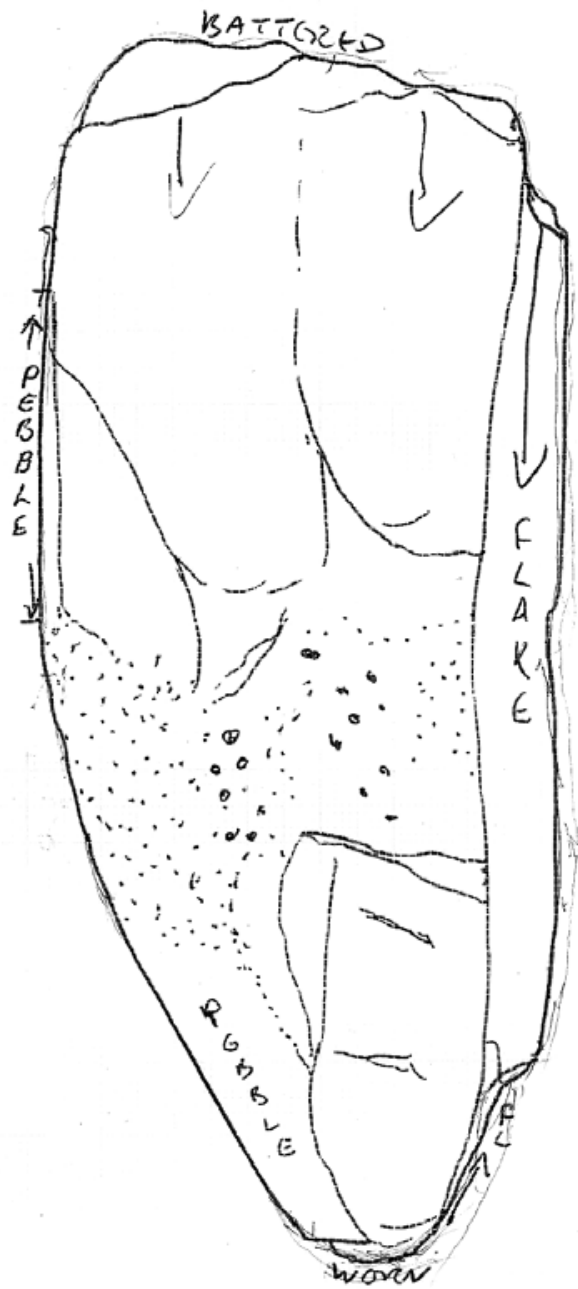

HAMAMER

HEAVILY BATTHCED FROM TUP END WORN ONLOWRE END CDTENDS OVER FLAKING WIDE PECKED AREA OVER ALL UN BROKEN CIRCUMEENENE $\therefore$ : SOME HEAVIER PECKING : NO PECKING JUER GLAKING. LIGHT GRGY LAMINATED SANPST ONE

Figure 5a. A measured field drawing of the stone tool CH89 no.33 from Copa Hill. Dibujo de campo a escala de la herramienta de piedra CH89 $n^{\circ} 33$ de Copa Hill. 


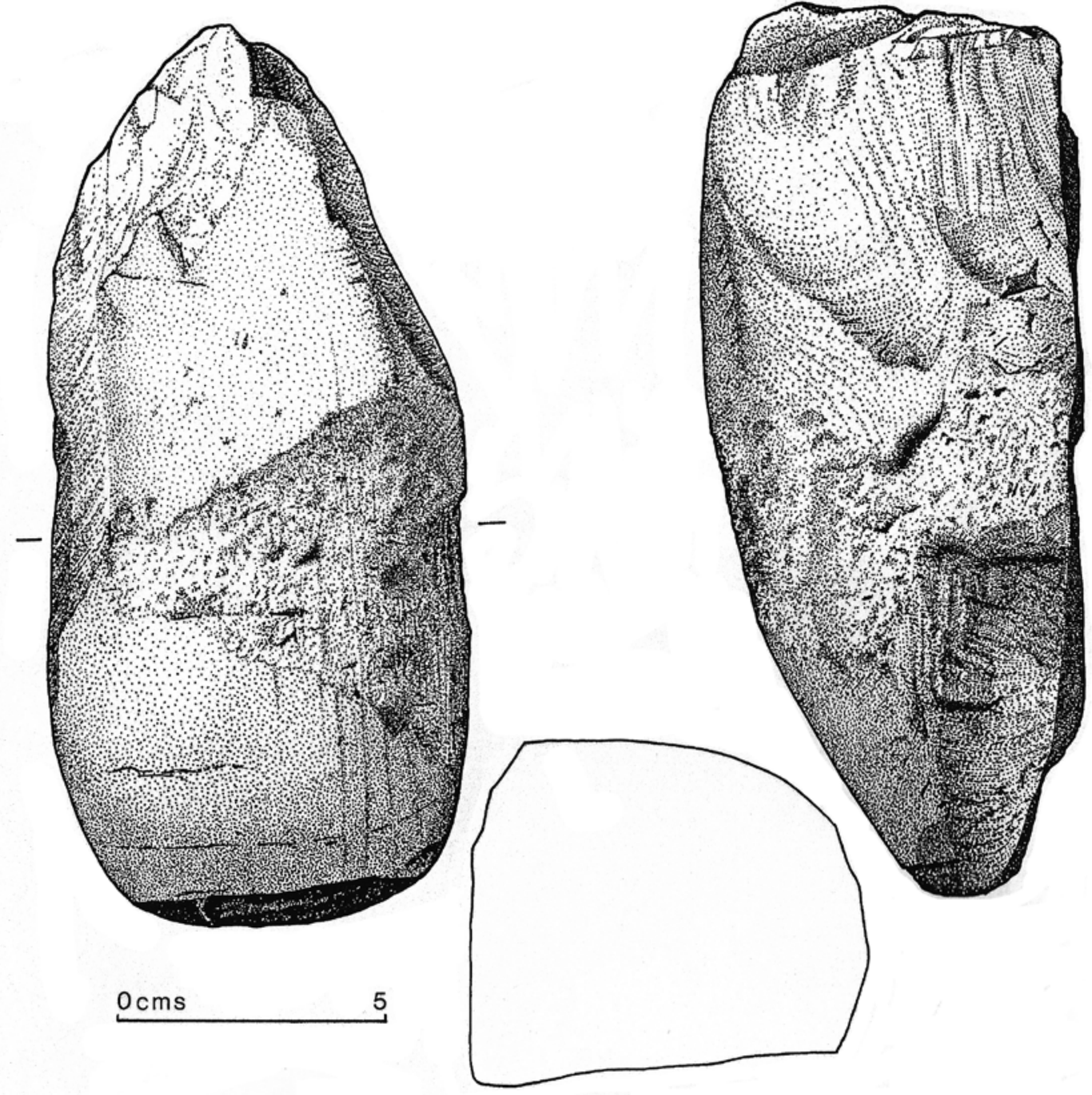

Figure 5b. An archive/ publication drawing of the same tool CH89 no.33.

Un archivo / dibujo de publicación de la misma herramienta CH89 no.33.

on site. These drawings are undertaken of all tools, and accompany the record sheets. Fine pencil and black ink drawings are produced for at least $65 \%$ of the hammers (see Figure $5 \mathrm{~b}$ for a finished drawing). These drawings are for the archive, but are of publication quality. Usually two faces of each tool are drawn, sometimes more, plus a longitudinal and horizontal profile. The surface texture of the cobble tool and any subtle modifications such as notching or bruising are shown by means of a fine stipple undertaken using the tip of a $0.2 \mathrm{~mm}$ graphic pen. All the tools are drawn lit from the top right-hand corner at $45^{\circ}$.
A standard two page hammer stone recording sheet has been developed by the Early Mines Research Group (Jenkins and Timberlake 1997; Timberlake 2003). For each of the tools a combination of morphometric, petrological and wear analysis data is recorded to look for evidence of a possible source for the cobbles and for any indication of selection based on shape, weight and cobble type, for evidence of primary and secondary tool use, artefact modification and usewear history (including any recycling or discard of the tool). Examples of the hammer stone data record key (Appendix 1), the standard recording sheet (Appendix 2) and visual 
roundness chart (Appendix 3) for classifying cobble shapes (all of which are essential to the system we use) are to be found at the end of this paper.

For each tool the essential categories we record are as follows:

(1) Identity (Archaeological context)

(2) Dimensions (weight is only recorded if the cobble is $>60 \%$ complete)

(3) Shape etc.-spherical [1] to flat [6]. For roundnesswe use Krumbein's cobble roundness indices (Krumbein 1941). Cobble smoothness: [1] = wave polish; [4] = rough.

(4) Petrology (e.g. grain size of rock, presence of cement or matrix, weakness (joints or cleavage), Moh's hardness scale (Moh's 3-8). Rock type: $\mathrm{A}-\mathrm{D}=$ sedimentary;

$\mathrm{E}=$ quartzite; $\mathrm{F}=$ igneous etc. These categories may be re-designed/ sub-divided to reflect the surrounding outcrop or glacial erratic geologies).

(5) Completeness $(<25 \%->75 \%)$

(6) Type of fracture (e.g. conchoidal, uneven or planar (premature) fracture)

(7) Wear analysis. Such as (1) evidence for hammering (i.e. the location of this as end, edge or side wear), pounding facets, mineral residue etc., (2) evidence for grindinguse; (3) crushing anviluse (either primary or secondary) or (4) re-use as a flake tool.

(8) Modification (i.e. the presence of notching or grooving for hafting/handgrip-either as primary or secondary use)

(9) Summary description of tool. A statement at the end of each record sheet which also includes an estimate of whether this had a short or long survival of use.

\section{Site specific study}

A specific study of cobble stone mining tools was undertaken at the Bronze Age mine on Copa Hill (Timberlake 2003). At least 79\% of the cobbles from here had scale 1 or scale 2 degrees of polish/ smoothness suggesting a possible origin as beach (littoral) pebbles, whilst 36\% or more had roundness indices exceeding that of local river (fluvial) pebbles (Krumbein 1941; Gale 1995).The average weightfor near-complete hammers found within the mine was $2-2.25 \mathrm{~kg}$, whilst for those larger fragments found outside of the mine on the tips it was less (i.e. between $1-2 \mathrm{~kg}$ ). The majority of the cobbles were between $15-25 \mathrm{~cm}$ long and $8-13 \mathrm{~cm}$ wide. These were cylindrical to flat-sided-suggesting a positive shape choice at source. There seemed to be some preferential selection of the finer grained and generally harder rocks amongst the greywacke cobbles; at least $42 \%$ of these greywackes werecomposed of quartz-cemented sandstones. Other than that there seemed to have been no vigilant selection to eliminate potentially flawed cobbles-to some extent this probably reflects the difficulties in detecting incipient joints in a well-rounded stone.

A survey of potential cobble sources within the Ystwyth Valley undertaken over the $25 \mathrm{~km}$ stretch of river valley between the mine and the sea indicated a 'best match' with pebbles taken from the storm beach shingle bars near the mouth of the Ystwyth River (Jenkins and Timberlake 1997). This probable source was determined by measuring three different parameters: the amount of 'flattening' of the pebbles, the degree of smoothness/ polish of the surface, and the presence or absence of beach pebble attrition (or 'chatter') marks. Natural selection of pebbles on a storm beach ensures hard, competent, flawless cobbles. From amongst these, the more cylindricalshaped pebbles were preferentially chosen. By contrast, unworn glacial erratic cobbles were very rarely found used as tools along with less than $30 \%$ of 'good fit' re-worked river pebbles.

Some $99 \%$ of the cobbles used at the mine were composed of greywacke sandstones-all of them geologically local to this area of mid-Wales. Most of the beach sources, however, contained upwards of $5 \%$ exotic igneous and metamorphic rocks, most left as glacial erratics by the Irish Sea ice from sources as far away as North Wales, the Lake District and Scotland. Although ideal for use as tool material, these 'exotics' were only rarely found used as hammersmost probably a reflection of the rarity of suitably sized/ shaped cobbles in these rock types.In general, lithology seems to be of secondary importance to cobble shape, size and weight. However, $66 \%$ of the hammers used or re-used as anvils were composed of the commonly harder quartzitic sandstones and/ or coarser grain size lithologies.

Tool functions represented amongst the used cobbles were assessed in the following proportions. The largest group (67\%) consisted of the actual mining tools themselves (rock-breaking hammers), with the crushing anvils (used or re-used) at $13 \%$, mallets or chisels $8 \%$, hand-held crushing tools $6 \%$, 


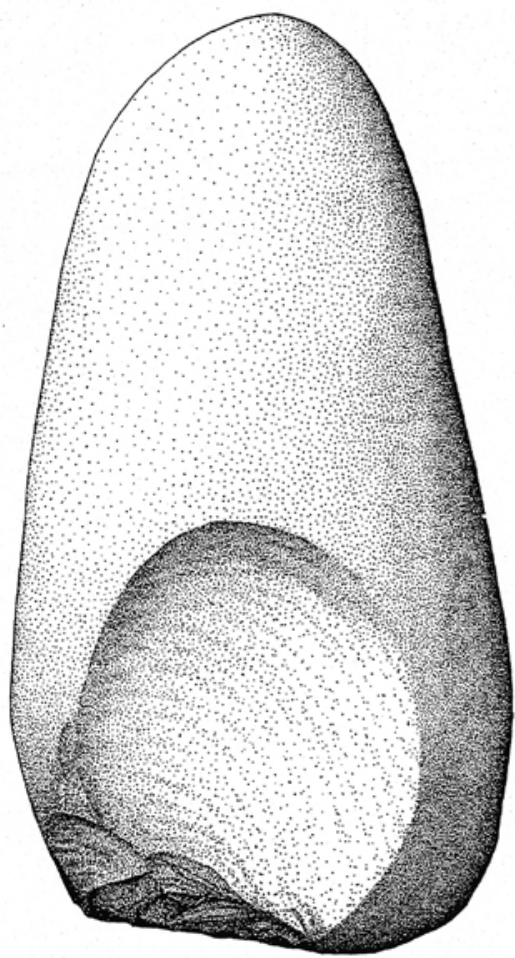

Figure 6. A Type A single-end mining hammer from Copa Hill. Martillo minero Tipo A de Copa Hill.

and re-used flake tools $6 \%$. The study of 1203 cobble stone tools revealed that only $9 \%$ showed indisputable evidence of modification for the purpose of hafting (this included 75 edge-notched hammers but only 4 semi-grooved examples). Meanwhile $41 \%$ of tools appear to have been re-used following initial breakage-some of them at least 3 or 4 times!

\section{Tool functions and types}

Tool types reflecting the utilitarian nature and interchangeable functions of the mining and beneficiation process have been found at all of the prehistoric mines investigated.

\section{The single-end mining hammer (Type A)}

This is the first category of un-modified, or poorly modified tool (Figure 6). It seems that many of these could have been hafted given recent experimental reconstructions of these tools

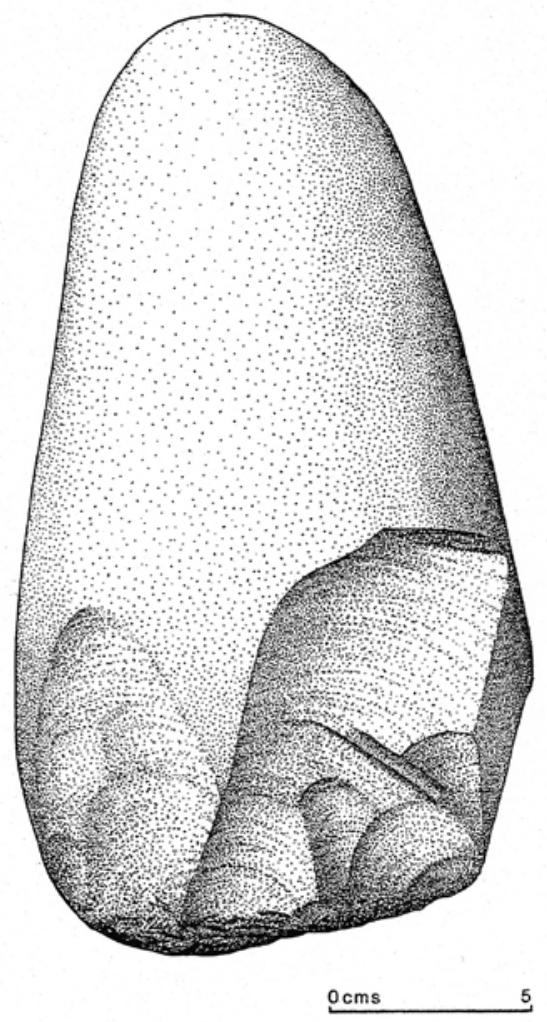

(Timberlake 2007). Some certainly would have been hand-held. Unmodified elipsoid-shaped cobbles are not common. During use the narrower ends of these cobbles would become more firmly wedged into the wrapped-around withy haft and not easily loosen. This has been confirmed experimentally. Figure 7 (7a) shows how this cobble may have been used.

\section{Double-end mining hammers (Type AA)}

All appear to have been hafted tools, most but not all of them being visibly modified cobbles. Rarely these are partially grooved (see Figure 5b), but more commonly these have lightly scratched to properly notched edges, sometimes with small indents on the flat sides to take a wedge of wood or stone such as a flake (Figure 8). These tools were used at alternate ends for picking or smashing rock, for heavy pounding, or as else mallets with other tools (Figure 7 [7b]). 


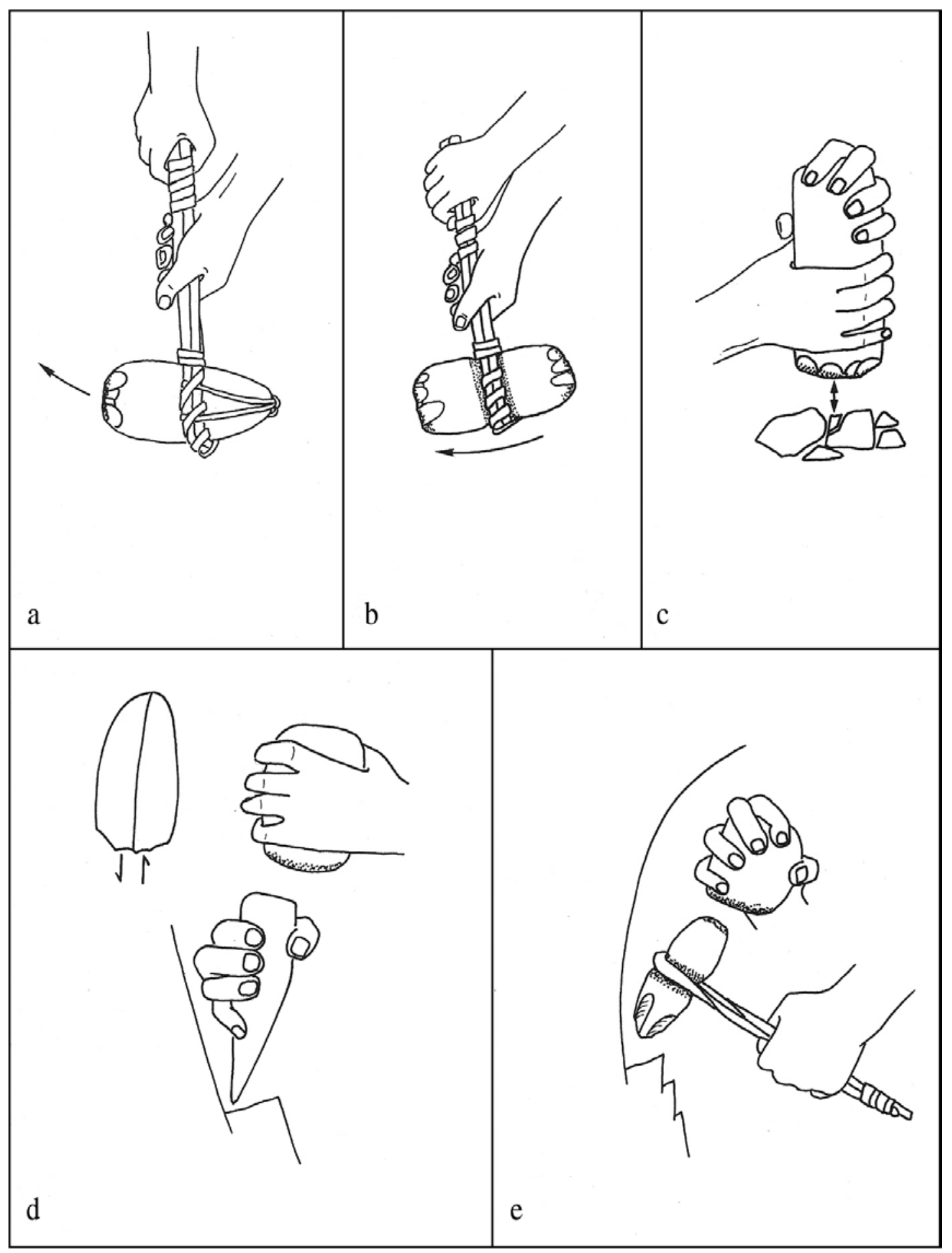

Figure 7a-e: The use of cobble stone mining tools-hafted end hammers (A + AA), crushing implements (C), picks, mallets and chisels (D).

a-e: El uso de herramientas mineras de piedra en cantos rodados: martillos enmangados $(A+A A)$, implementos de molienda (C), picos, mazos y cinceles $(D)$. 


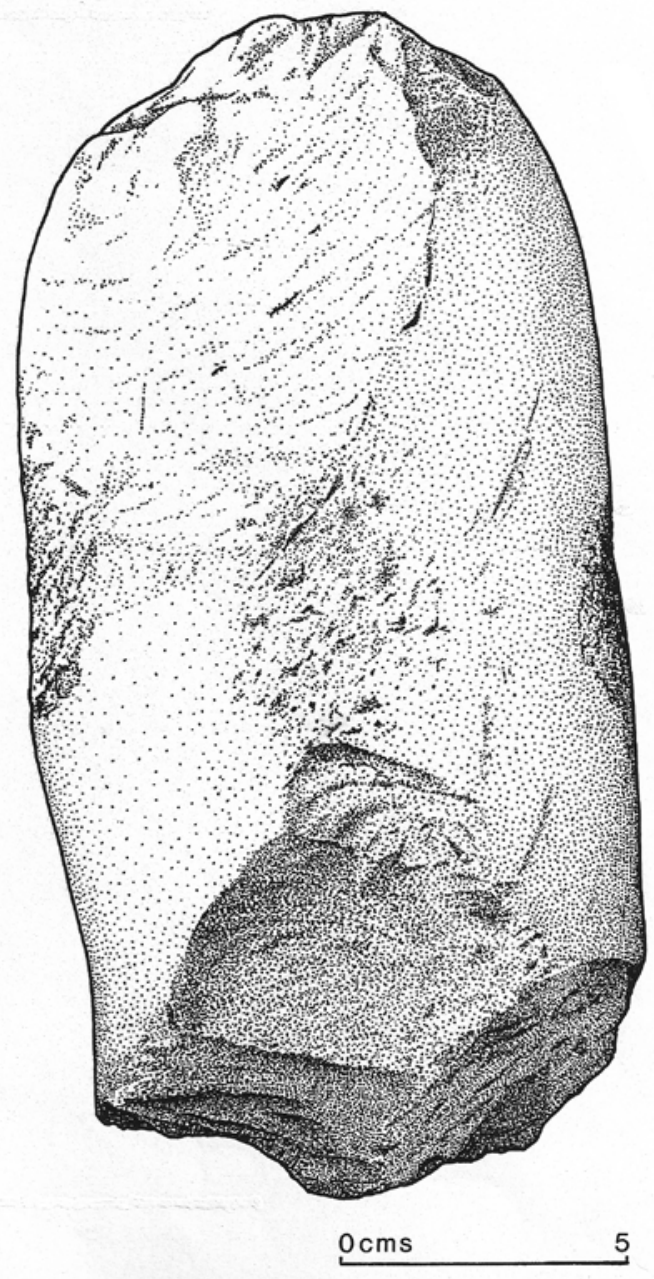

Figure 8. A Type AA double-ended mining hammer (modified for hafting) from Copa Hill.

Martillo minero del tipo AA (modificado para enmangue) de Copa Hill.

\section{Crushing tools (Type C)}

These are generally larger ( $8-20 \mathrm{cms}$ long) handheld tools used for breaking up ore and crushing mineral (see Figure $9(a-c)$ ). The example shown in Figure 9a is the broken-off end of a mining hammer which has been re-used (Figure 10 (10a)). Another common type of crushing implement (Type C3) consists of a small cobble worked around its outer edge possessing distinct crushing facets (Timberlake 2005a, 2006). These were sometimes discoid in shape (Figure 9c) on account of how they were held and worked (Figure 10b). Typically these may have been for crushing small pieces of mineral. Larger hand-held hammer stones (up to $1.5 \mathrm{~kg}$ ) were also used for crushing purposes (Figure 7c).

\section{Picksorchisels (Type D)}

These were usedfor levering-off rock and for small extraction work. Commonly we find these modified (notched) and re-used. Typically cobble edges have been removed through use; often these are re-used flakes detached from hammers, but sometimes they are remnant cores (Figure 11). Most were probably held in a short haft and used with or without a mallet (Figure 7d-e). Flakes re-used as small chisels or wedges can generally be recognised from the rounding of the fracture surface.

\section{Crushing anvils (Type E)}

These were used for the pounding and crushing of small pieces of ore. Depending upon the degree of use and the type of work carried out these anvil stones might have flat (Figure 12a) or slightly indented surfaces (Figure 12b). More than $50 \%$ of the examples of this type were actually fractured and split mining hammers re-used on the flat fracture surface as anvils (Figure 10c).

\section{Pecking stones (Type F)}

These are rarely found. These were used for notching hammer cobbles (Figure 10d). The few found were small (5-8 $\mathrm{cm}$ diameter), round and hard rocks-typically a vein quartz or quartzite pebble.

\section{The saddlequern-type mortar stone (Type G)}

This is a slab used for the fine grinding of an ore mineral mix or perhaps a copper smelting slag for the purpose of separating-out the metal prills (Figures 13 and 10e). These are very rare finds; single examples coming from Copa Hill (Timberlake 2003: 98D) and from Ross I. Killarney, Eire (O'Brien 2004: 359).

\section{Grooved mining hammers (Types $2 A$ and $3 A$ )}

The prehistoric mines of Alderley Edge are unique for Britain in that $93 \%$ of the cobble stone mining tools from there show clear evidence for haft modification (either as notching (e.g. Type 2 


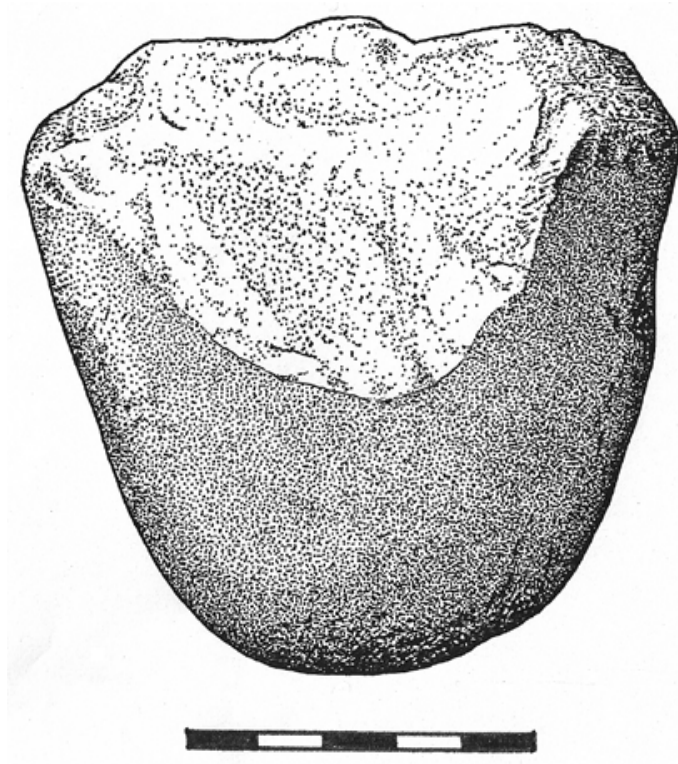

Figure 9a. A Type C hand-held crushing tool from Copa Hill. Herramienta de molienda manual del Tipo C proveniente de Copa Hill.

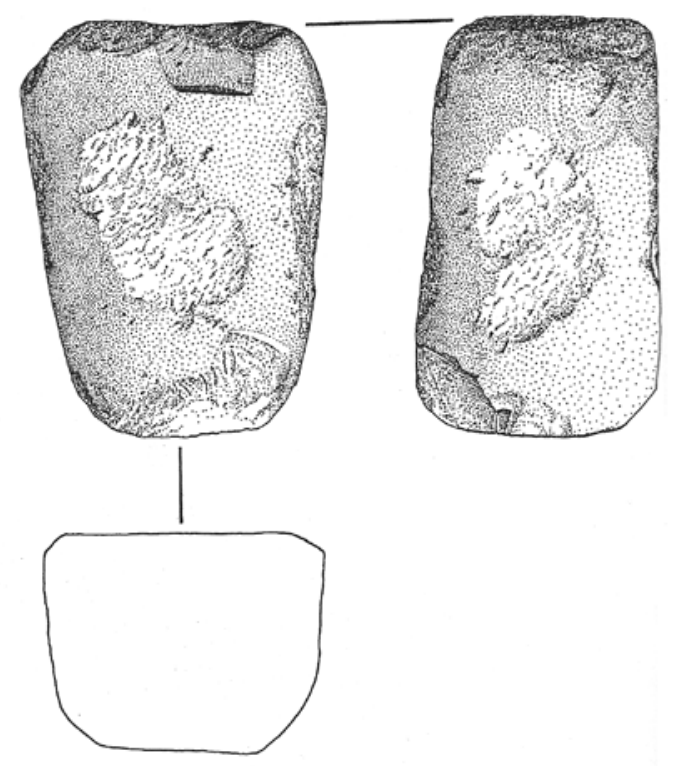

Figure 9b. A Type C2 crushing tool from Copa Hill. Herramienta de molienda del Tipo C2 proveniente de Copa Hill.

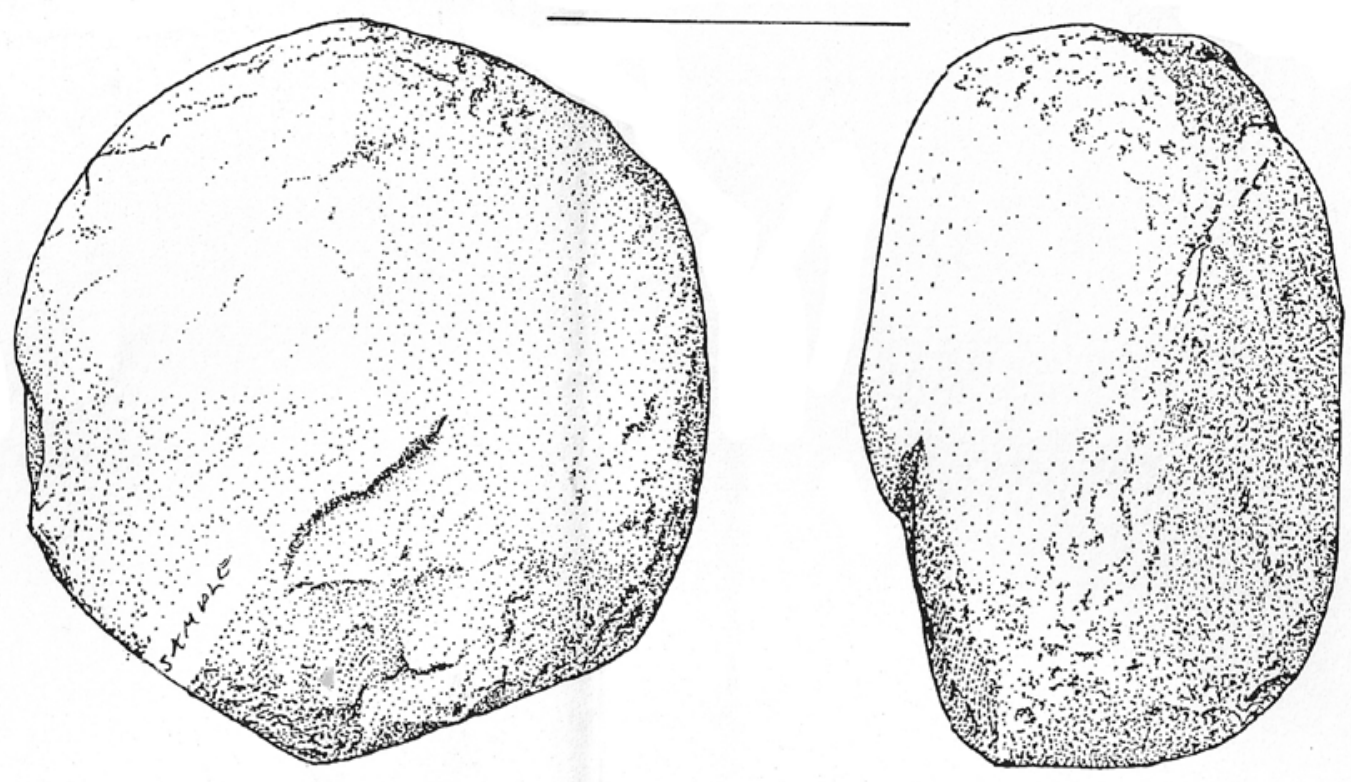

Figure 9c. A Type C3 (discoid) hand-held crushing tool from Engine Vein, Alderley Edge.

c. Herramienta de molienda manual del Tipo C3 (discoidal) proveniente de Engine Vein, Alderley Edge. 


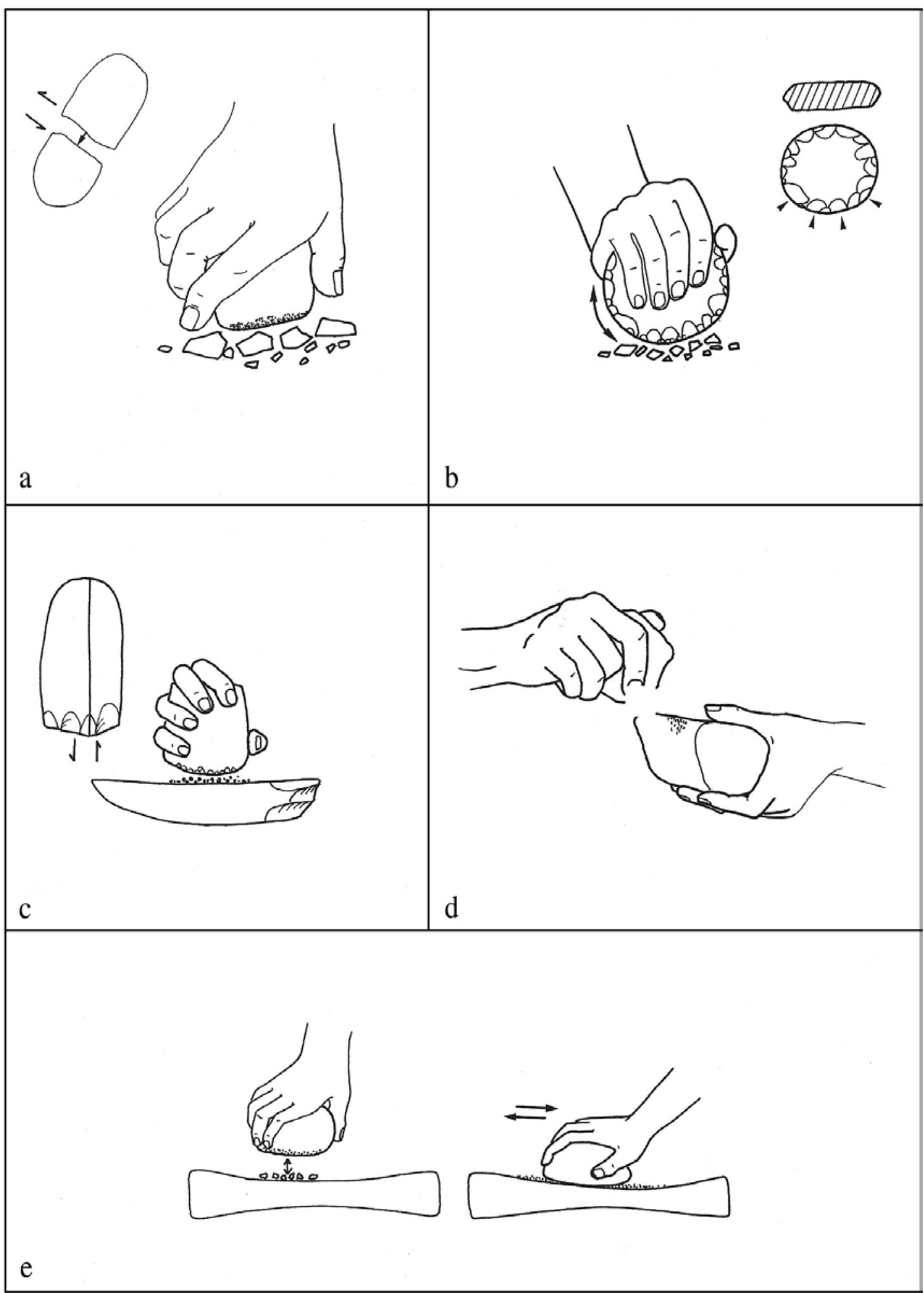

Figure 10a-e. The use of cobble stone tools-crushing implements $(\mathrm{C} 1+\mathrm{C} 3)$, anvil stones $(\mathrm{E})$ and a saddlequern-type mortar $(\mathrm{G})$. a-e: El uso de herramientas de piedra de cantos rodados: implementos de molienda $(\mathrm{Cl}+\mathrm{C} 3)$, yunques $(E)$ y un mortero del tipo saddlequern tipo $(G)$. 
modification) or fully-developed grooving (Type 3 modification)). Therefore, in terms of the current classification of tool use/types a grooved singleended mining hammer would normally be referred to as Type $3 \mathrm{~A}$, whilst a double-ended hammer would be referred to as Type 3AA. In contrast to this, a notched or else only partially-grooved mining hammer would be a Type $2 \mathrm{~A}$ or $2 \mathrm{AA}$. However, at the time the Alderley stone tools were first being recorded a slightly different typology was in place (Timberlake 2005). Here the two classifications have been integrated.

The cobble source used at this inland site is the local glacial drift (or Boulder Clay) which contains large numbers of Lake District rocks from the North
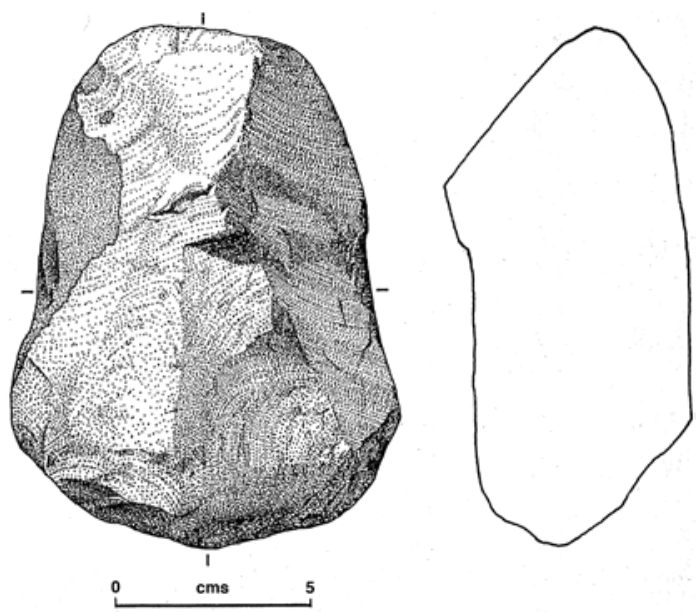

Figura 11. A Type D pick or chisel from Copa Hill.

Pico o cincel del Tipo D de Copa Hill.
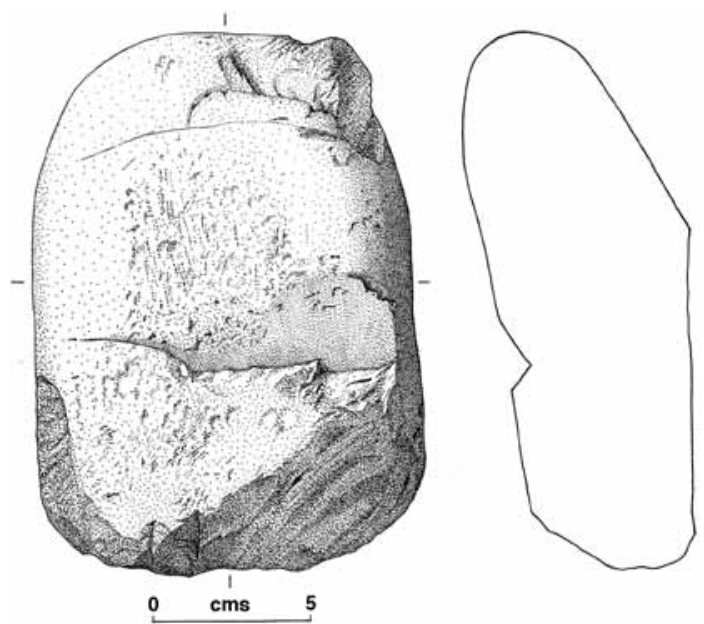

Figure 12a. A Type E crushing anvil (flat cobble surface) from Copa Hill.

Yunque (superficie plana de canto rodado) del Tipo E de Copa Hill. of England. These include the hard greywackes, the Shap granite, and also the andesites, basalts and tuffs of the Borrowdale Volcanic Series (Browne 1995). We also find a similarly high level of recyclingthough perhaps less so than at the upland Welsh mines. The cobbles may well have been grooved because they survived for longer without fracturing when used against the softer sandstone/conglomerate country rocks.

Types $3 \mathrm{~A}$ and $3 \mathrm{Ab}$ are axe or pick-shaped grooved single-end mining hammers, some of which show extensive haft wear around the median groove, and commonly the insertion of a butt-end groove over the broader top end (Figure 14). Butt-end grooves and additional lateral grooves (Type $3 \mathrm{Ah}$ ) were probably inserted as a response to wear-related movement in the haftings, and perhaps also because of the geometry of the cobble when the narrower 'pick' end of the tool was used.

\section{The boulder battering stone (Type 2I)}

This is a very large utilised cobble (usually $>8$ $\mathrm{kg}$ in weight) which might have been used slung from a rope on a tripod against the rock face (Figure 15). The probability and effectiveness of this arrangement was aptly demonstrated during experiments carried out with such boulders on the Great Orme in 1989-quite a few large cobbles or boulders this size have also been found used as tools within the prehistoric mine (Lewis 1990).
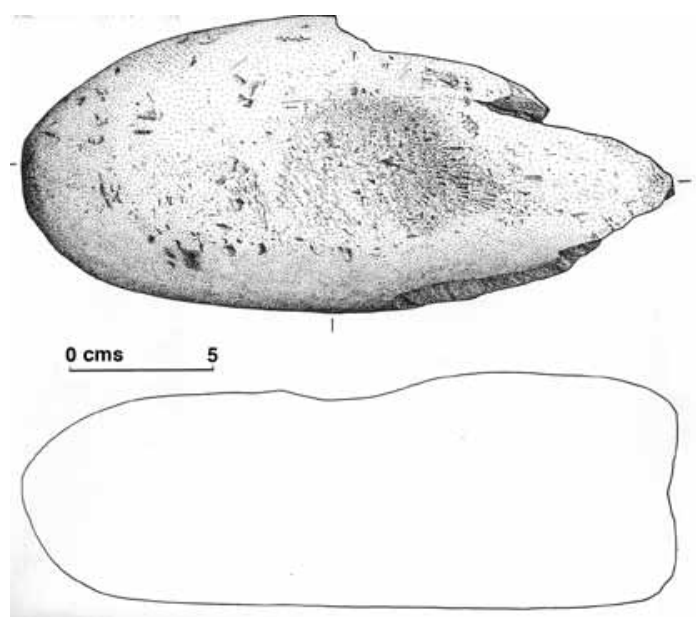

Figure 12b. Type E crushing anvil (indented cobble surface) from Copa Hill.

Yunque (superficie con surco) del Tipo E de Copa Hill. 


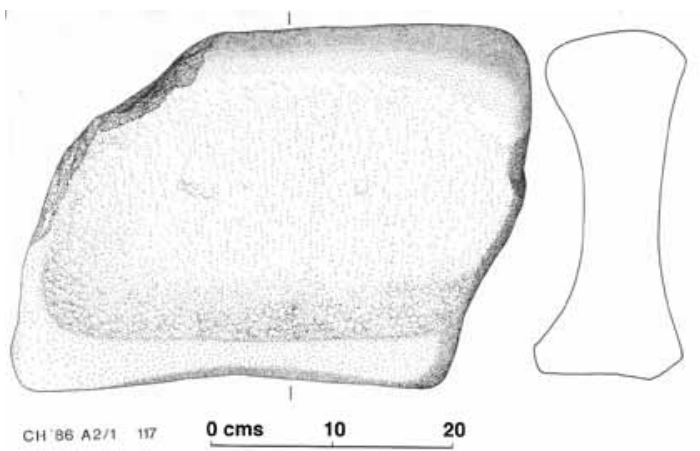

Figure 13. A saddlequern-type mortar stone (Type G) from Copa Hill.

Mortero del Tipo G de Copa Hill.
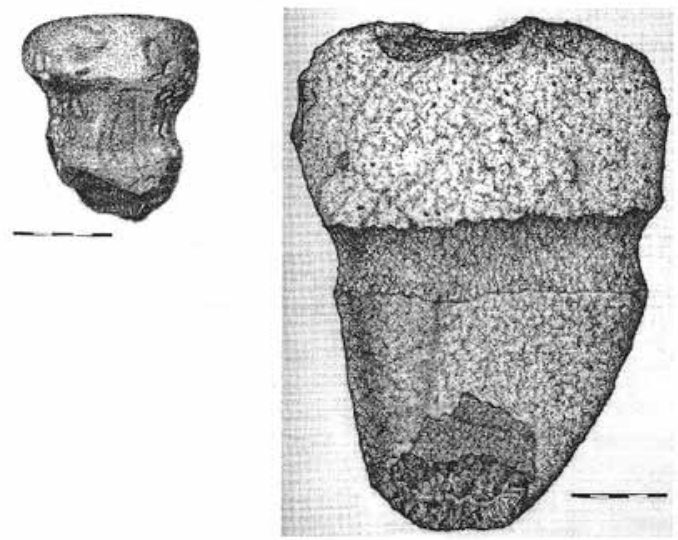

Figure 14. Type $3 \mathrm{~A}$ and $3 \mathrm{Ab}$ grooved mining hammers from Alderley Edge (Manchester Museum collection + drawings). Martillos mineros con escotadura de los Tipos $3 A$ y $3 A B$ de Alderley Edge (colección del Museo de Manchester + dibujos).

\section{The chemical analysis of mineral residues}

An attempt was made to undertake residue analysis on some of the Copa Hill tools in order to try and determine whether or not some of the mineral stain on the ends of hammers or on crushing anvils contained enhanced metal from the original processing activities (Jenkins and Timberlake 1997). The examination of the surface of a dolerite anvil stone was carried out using SEM-EDXRA (Energy Dispersive X-Ray analysis) and PXRF (Portable $\mathrm{X}$-Ray Fluorescence). Two spots on an area of manganese/iron stain associated with this crushing were examined by SEM-EDXRA. The spectra of the surface showed enhanced lead compared to the fresh rock underneath. The PXRF scan of the
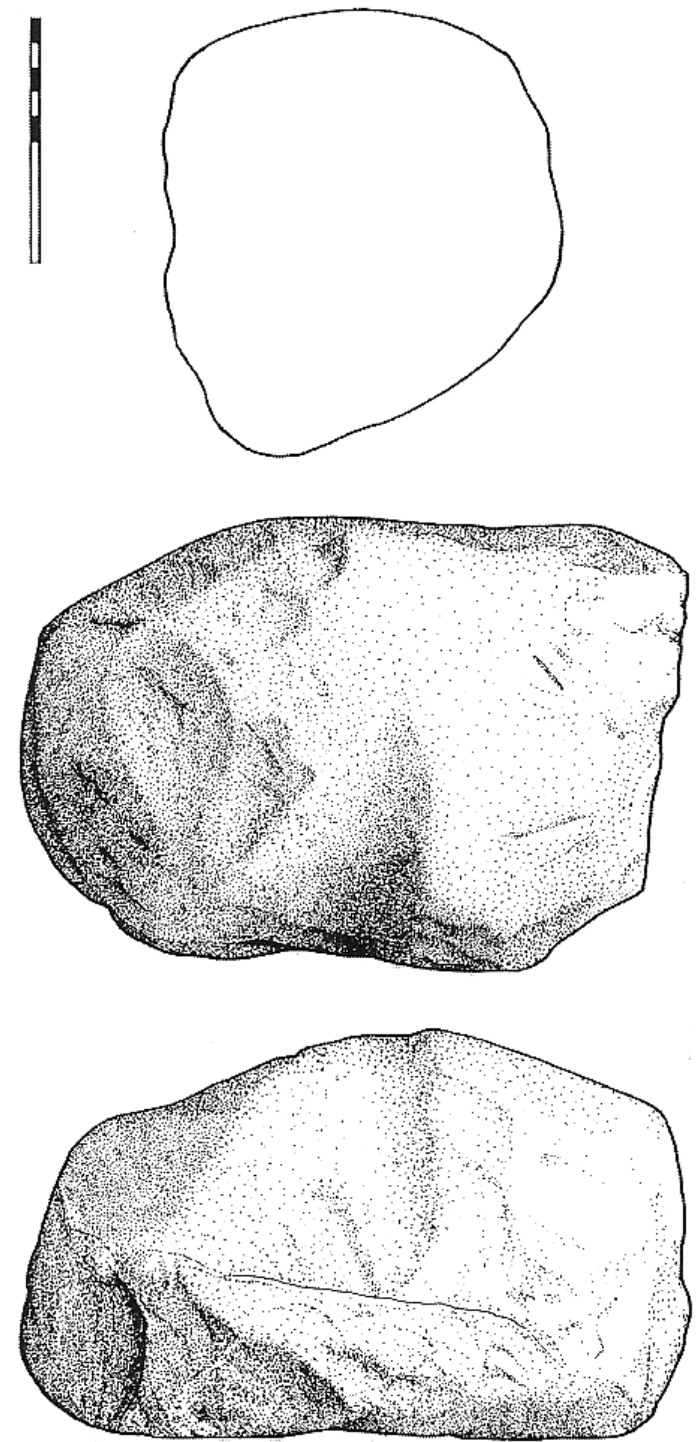

Figure 15. Type 2I-a large boulder of $16 \mathrm{~kg}$ used as a hammer (and probably swung from a tripod) Engine Vein, Alderley Edge. Tipo 2I-un gran canto de $16 \mathrm{~kg}$ utilizado como martillo, Engine Vein, Alderley Edge.

whole surface was more interesting in that it showed greatly enhanced lead and zinc, though this was in inverse proportion to that expected, being higher on the outside of the central iron stained area, than in the middle. Copper, on the other hand, was marginally elevated centrally (though the expected background values for copper in the dolerite were too high for this to be conclusive). The results of this preliminary work would seem to suggest potential in these techniques for future investigation. 


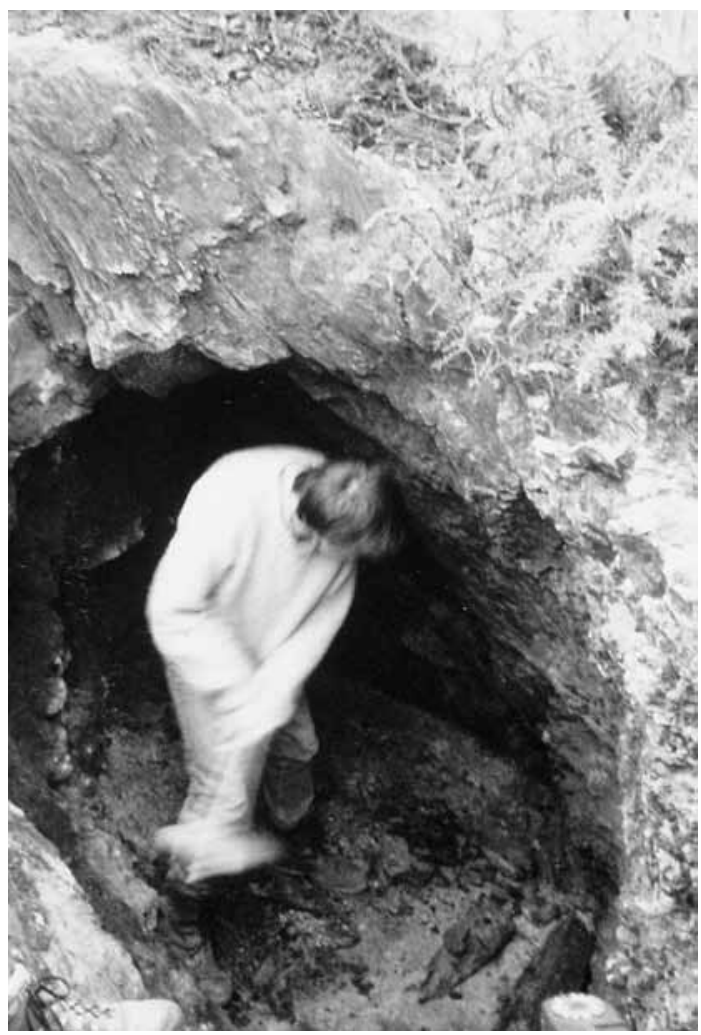

Figure 16. Experimental mining with a hafted cobble stone tool in North Wales in 1989.

Minería experimental con una herramienta de canto rodado enmangada en el norte de Gales en 1989.

\section{Experimental archaeology}

One of the most interesting aspects of this work has been to undertake archaeological experimentssuch as the making and using of hafted cobble stone mining hammers (Craddock et al. 2003; Timberlake 2007).As part of this, one of us (BC) undertook a workshop in the making and using of grooved stone tools at Alderley Edge in 1997. Using a small pecking stone a groove of between 1-10mm deep and $15-20 \mathrm{~mm}$ wide was cut around the circumference of a $100 \mathrm{~mm}$ diameter cobble in approximately one hour (Timberlake and Craddock 2005). In retrospect what we found following their hafting and use was that there we didn't need to peck much of a groove on the flat surfaces. We found the same thing on some of the archaeological examples. Making the handle for the tool involves bruising and twisting a hazel withy (approximately $1.2 \mathrm{~m}$ long) and then bending and tying this around a cobble and binding it with rawhide. In reconstructing the Alderley Edge

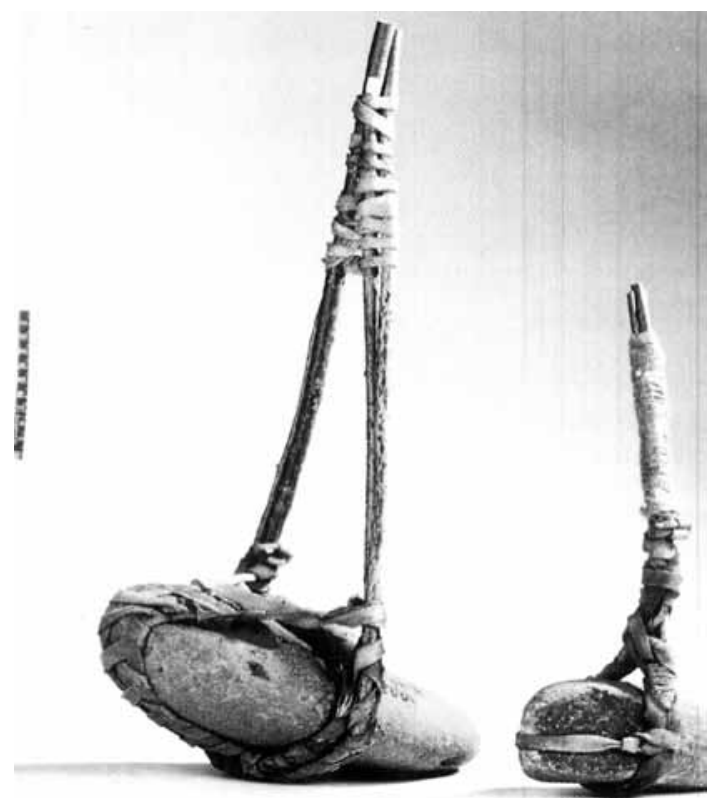

Figure 17. Several well-used experimental mining hammers hafted in twisted hazel (Corylus sp.) with rawhide and hemp bindings (EMRG 1990).

Varios martillos experimentales con mango de avellano trenzado (Corylus sp.). El enmangue fue realizado con cuero y cáñamo (GIMT 1990).

tools, similar cobbles to those we find archaeologically were collected from the local Boulder Clay deposits. Archaeological experiments such as this can help us to understand the manufacture, function, and usewear on these tools. They can also be used to predict archaeological findings.

Our original experiments using these tools were carried out in 1988 and 1989 at our Penguelan experimental site at Cwmystwyth, and also near Maentwrog in North Wales (Figure 16), where we had been firesetting on a vein (Pickin and Timberlake 1988; Timberlake 1990b). Later we tried using hammers hafted with freshly-cut green willow handles (Craddock 1990). These proved to be too flexible which made it difficult to accurately direct the tools against the rock. Following this, un-grooved cobble stone mining hammers with a hafting modelled on the Chuquicamata-type were experimented with in the early 1990s (Craddock et al. 2003). These proved quite successful; one of these tools (Figure 17) removed 1.5 tons of rock without any serious breakage of the cobble. In 1997 the grooved cobble stone hammers were quite effective when experimented with at Alderley Edge against previously fireset sandstones and conglomerates (Timberlake 2005b). 


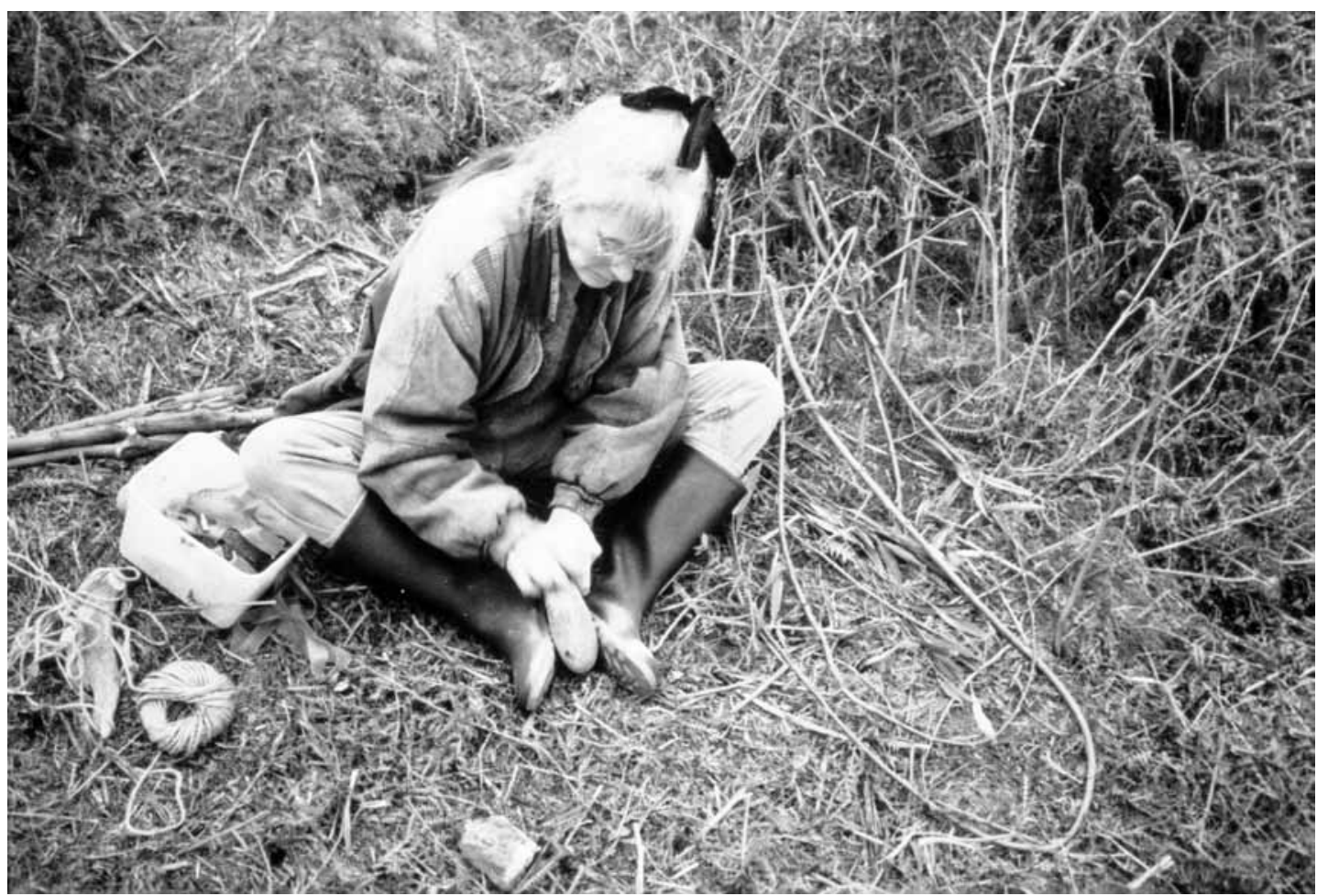

Figure 18. Brenda Craddock repairing (re-hafting) a stone hammer during an experimental mining session in 1990.

Brenda Craddock reparando (re-enmangado) un martillo de piedra durante una sesión de minería experimental en 1990.

The important thing to remember in the use of these is that the hammers need to be swung underarm against the rock, using the weight and momentum of the hammer as well as the bounce of its return to help loosen joints and cleavage planes previously weakened by firesetting. Continual repairs of broken hammer hafts are an equally important part of the mining process (Timberlake and Craddock 2005). We have estimated that somebody would need to be on-hand to repair these every half hour or so. This person would have been an essential member of the mining team (Figure 18).

Experimental archaeology has enabled us to frame our concepts of how these cobble stone hammers were used, and also to explain why in some cases these cobbles only required the most minimal of modifications for the purposes of hafting. Key elements to the successful use of these hafted tools (as rock-breaking hammers) included carefully aimed under-arm blows against the rock, using the weight of the stone to maximize the strength of impact, and also allowing the force of this to bounce the hammer away from the rock face. Premature fractures within these hammer stones occurred most frequently where the cobbles were poorly chosen, possessing weak lithologies, joints and cleavage, and least of all within those cobbles made of hard quartzitic sandstone or dense crystalline igneous rock. Such cobbles broke up slowly through gradual spalling or flaking from the tip. In fact the failure of the hafting as a result of the loosening of the withy binding resulting from the repeated impact was probably a much more significant limiting factor to survival than the actual degree of modification or grooving of these stones. For instance, our experimental work has shown how important the construction of a hafting cradle was to securing the rear of the mounted cobble in a mining hammer; such an understanding only being reached after many, many hours of repairing hafts for stone tools. This realisation also perhaps helps explain the complexity of the bindings we find on some of the surviving Pre-Columbian hafted tools from the Atacama (Chile), as well as the occurrence of lateral and butt-end grooves on some of the presumably longer-lasting examples of Alderley Edge and Mali Sturac hammer stones in use more than three millennia earlier (see 


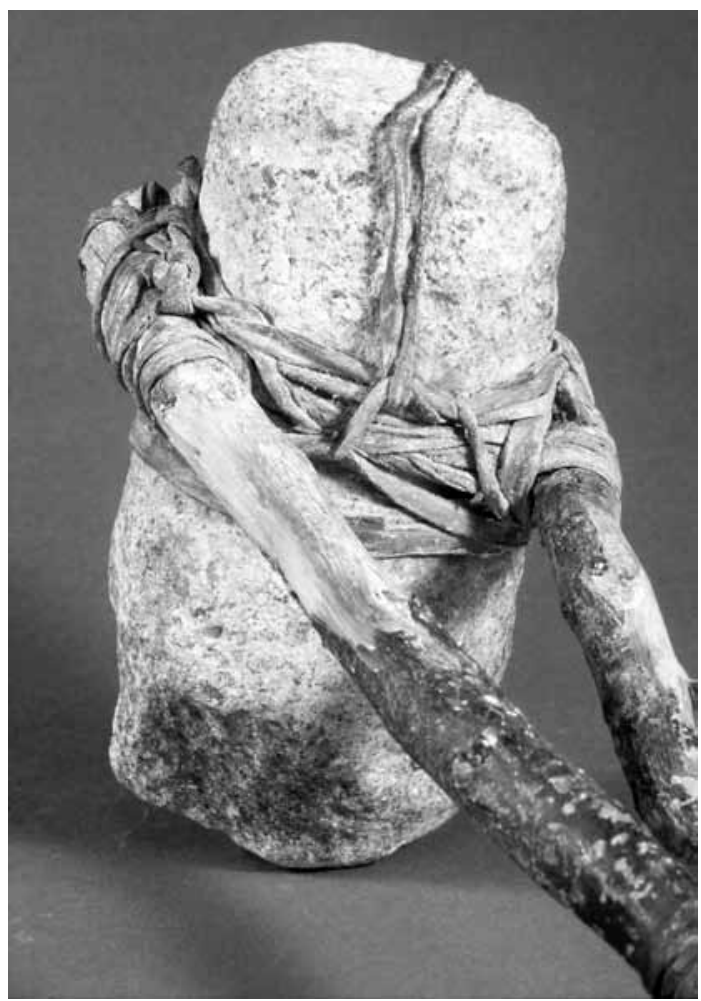

Figure 19: The William Wray Pre-Columbian stone mining hammer from Chuquicamata, Chile, during conservation at The British Museum in 1995 (photo Paul Craddock).

Martillo minero precolombino de William Wray procedente de Chuquicamata (Chile) durante su conservación en el Museo Británico en 1995 (foto de Paul Craddock).

Timberlake and Prag 2005:71; Bogosavljevic 1988). Such experimental findings would seem to support the idea that the type of tools and methodology of mining tool use was fairly universal within pre-iron using societies. In the same way during these experiments the re-cycling of broken and initially discarded hammerstones became a spontaneous and natural part of the mining process (Timberlake 1990b, 2003, 2007); with such simple undifferentiated tools developing an increasingly complex range of opportunistic function as chisels, hand-crushing tools, and anvils. Indeed the subtle range of use-wear traces on these resulting from their re-hafting and re-use for the purposes levering, scraping, hammering and crushing was found to match many of those wear marks previously proposed as defining similar tool categories within archaeological examples (Timberlake 2007). One such experimentally defined tool, a flat cobble stone hammer re-used as a crushing anvil, appears at
Cwmystwyth, as well as at the Stone Age hematite mine at Taltal in Chile.

\section{Ethnographic evidence}

Archaeo-ethnographic evidence can be helpful in understanding how tools were made and used. However, exceptional cases apart, the use of this is probably limited. One very important example, of course, was the toolkit of the Chuquicamata 'Copper Man' (Bird 1979). For us, the most useful exercise was the study and experimental replication by Brenda Craddock of another hammer from Chuquicamata (Figure 19) loaned for conservation to the British Museum in 1995 by Willliam Wray (Craddock et al. 2003). There are other similar examples within ethnographic collections, though none are certainly mining tools.

Interestingly there are examples of stone mining tools still being used. Worthington \& Craddock (1996) describe a crushing tool and mortar for grinding gold-bearing quartz in Uganda in 1996, whilst similar 'hand maul' crushing stones are to be found from the $14^{\text {th }}$ - century AD right up until recent times within the gold workings at Tembellini in Mali and in the Ashanti goldfield (Laffoley 1998). Paul Craddock (1995:162) illustrates stone anvils/ mortars still being used for the crushing of lead/zinc ores at Ishiagu in southern Nigeria. Interestingly, the use of cobble stone tools as actual mining implements only seems to pre-date the introduction of high quality wrought iron into sub-Saharan Africa at the beginning of the $19^{\text {th }}$-century. It seems that stone mining tools were still being used within the copper mines of Zimbabwe, alongside the use of iron, prior to the arrival of Europeans. The exceptional continuation of earlier and outdated practices is also interesting. For example, there are a number of well-documented contemporary images of Kenyan smiths using hafted stone tools to forge iron (Brown 1995). Similar tools over $6 \mathrm{~kg}$ in weight have also been found within some of our own Bronze Age mines. This is hardly the same process, yet it is a revelation to see such large cobble stone tools being handled accurately and apparently with ease.

\section{Conclusions}

In Britain during the Early Bronze Age beach cobbles were preferentially transported inland for 
up to $25 \mathrm{~km}$ from the coast for use as tools within the mines. These cobbles were largely unmodified. Fully grooved cobble stone mining hammers are only found at Alderley Edge in England (and at the Ross Island in Ireland). Both of the latter are inland sites. At the other inland sites, Nantyreira in mid-Wales and Ecton in Staffordshire crude un-modified river pebbles or glacial cobbles have been used as tools.

Most hammers are between 1-2 kg in weight, the majority being composed of quartzitic sandstone or a dense igneous rock, typically cylindrically shaped, with a smooth rather than rough, and a rounded rather than angular form. We see preferential tool types developing-yet the differences between these are subtle. Tools can be multi-functional, with re-use rather than disuse following breakage being the norm. Recycling of tools is greatest in those areas of hard rocks. This seems to be proportional to the rate of breakage and distance from the source. Typically hammers are used against fireset or else very weathered rock, and were probably swung at this underarm.

In our view this is a completely utilitarian technology which could, and almost certainly did develop spontaneously and independently across the globe at the very beginning of the first metal working period(s); a product of environmental determinism rather than diffusionism. Given the obvious similarities between the assemblages of cobble stone mining tools found at the 10000 year old hematite pigment mine of San Ramón 15 near Taltal, Chile and at the 4500 year old copper mine on Copa Hill, Cwmystwyth in Wales, what then are the differences? The former should have implements for the fine grinding of hematite, but beyond that, is it possible to see some of the same functional types of tool appear (in both) as a result of the similar utilitarian needs linked to the development of the mine, and the ensuing wear and fragmentation of these cobbles? The collection and use of cobbles as mining tools reflects the continuation of what is effectively a stone age technology employed in the earliest extraction of ores and the production of metal. In general terms the stable ergonomics of stone tool use pre-dates the arrival into general circulation of bronze in such abundance and availability as to be consumed as partially expendible mining tools, by those individuals of low or modest status undertaking the mining activity (Shennan 1999). This seems to be the situation in Europe up until the Middle Bronze Age-Late Bronze Age expansion in metal production (in Britain the situation is less clear-there is a complete absence of identified Late Bronze Age mines), but in the pre-Hispanic Americas this tradition of using stone tools in the mining of metal ores or minerals lasts some 11,500 years. This continuity of mining tool use up until the end of the Inca period within the Andean zone offers us the opportunity to examine what changes, if any, take place over time in terms of the design of this conservative and quite minimalist technology. Given the record of preservation of some of the organic components of these tools within this arid region, an in depth study of this cobble stone mining tool technology within the Atacama region seems well placed and timely. We hope that this account of our work, including the recording system we have field tested, will prove to be of some practical use to the future investigation of ancient mining in the Americas.

Acknowledgements: We would like to acknowledge the support of the various archaeological sponsors who have supported this research in the UK, in particular the National Museum of Wales, The British Museum, British Academy, English Heritage, The Leverhulme Trust, The National Trust, Board of Celtic Studies and the Cambrian Archaeological Association. This work would not have been possible but for the total commitment of the excavation team of the Early Mines Research Group. Our heartfelt thanks to the OrganizingCommittee of PRIMPA (Diego Salazar, Valentina Figueroa and Paulina Corrales) for inviting one of us (ST) to Chile to present this paper, and the evaluators for commenting on the text of this prior to publication. 


\section{References Cited}

Barnatt, J. and G. Thomas 1998. Prehistoric mining at Ecton, Staffordshire: a dated antler tool and its context. Mining History (Bulletin Peak District Mines Historical Society) 13 (5):72-78.

Bateman, T. 1855. A Descriptive Datalogue of the Antiquities and Miscellaneous Objects in the Museum of Thomas Bateman at Lomberdale House, Derbyshire. Sheffield City Museum, Sheffield.

Bick, D.E. and W. Davies. 1991. Lewis Morris and the Cardiganshire Mines. National Library of Wales, Aberystwyth.

Bird, J.B. 1979. The 'Copper Man': A Prehistoric Miner and his Tools from Northern Chile. In Pre-Columbian Metallurgy of South America, edited by E. P. Benson, pp. 359-371. Dunbarton Oaks, Washington.

Bogosavljevic, V. 1988. Materiel archeologique meuble de la mine prehistorique de Prljusa-Mali Sturac IN Jovanovic, B.: Recherches sur l'Exploitation Minière et la Metallurgie Anciennes dans la Region du Radnik. Cacak.

Briggs, S. 1976. Note on prehistoric mining in Anglesea. Historical Metallurgy 10 (1):43.

- - - 1993. Early Mines in Wales again: a reply to Budd. et al. 1992. Archaeology in Wales 34:13-15.

Briggs, C.S. 1983. Copper mining at Mt.Gabriel, County Cork: Bronze Age bonanza or post-famine fiasco? Proceedings of Prehistoric Society 49:317-333.

- - - 1988. The location and recognition of metal ores in PreRoman and Roman Britain and their contemporary exploitation. In Acta of British School in Athens Centenary Conference on Ancient Mining and Metallurgy, edited by J. Ellis-Jones, pp. 106-114. University College of North Wales, Bangor.

Brown, J. 1995. Traditional Metalworking in Kenya. Cambridge Monographs in African Archaeology no.38. Oxbow Monograph, Oxford.

Browne, T. 1995. The Mysteries of Alderley Edge. The North West Geologist 5:18-21.

Craddock, B.R. 1990. The experimental hafting of stone hammers. In Early Mining in the British Isles: The Proceedings of the Early Mining Workshop at Plas Tan y Bwlch, Snowdonia National Park Study Centre, edited by P. Crew and S. Crew, pp. 58. Plas Tan y Bwlch Occasional Paper 1.

Craddock, B.R., C.R. Cartwright, P. T. Craddock and W.B. Wray. 2003. Hafted Stone Mining Hammer from Chuquicamata, Chile. In Mining and Metal Production through the Ages, edited by P. Craddock and J. Lang, pp. 52-68. The British Museum Press, London.

Craddock, P. 1995. Early Metal Mining and Production. Edinburgh University Press, Edinburgh.

Davies, O. 1935. Roman Mines in Europe. MacMillan, London.

- - - - 1936. Report of the Annual Meeting of the British Association for the Advancement of Science (Section H), Early Mining Sites in Wales, pp. 304-305.

- - - 1938. Ancient Mines in Montgomeryshire. Montgomeryshire Collections 45: 55-60; 152-157.
- - - 1939. Excavations on Parys Mountain. Transactions of the Anglesey Antiquarian Society and Field Club: 40-42.

Davies, O. 1947. Cwm Ystwyth Mines. Archaeologia Cambrensis 99:57-63.

Davies, W. 1815. The Agriculture of South Wales, Volumes 1 \& 2, Cardiff

Dawkins, W.B. 1875. On the stone mining tools from Alderley Edge, Cheshire. Journal Anthropological Inst. of Great Britain 14:74-90.

Gale, D. 1995. Stone tools employed in prehistoric mining. $\mathrm{PhD}$ thesis, Department of Archaeological Sciences, University of Bradford, Bradford.

Jenkins, D.A. 1995. Mynydd Parys Copper Mines. Archaeology in Wales 35:35-37.

Jenkins, D.A. and S. Timberlake. 1997. Geo-archaeological research into prehistoric mining for copper in Wales. $\mathrm{PhD}$ Thesis, Leverhulme Trust, University of Wales, Bangor.

Krumbein, W.C. 1941. Measurement and geological significance of shape and roundness of sedimentary particles. Journal of Sedimentary Petrology 11(2):64-72.

Laffoley, N. 1998. Primitive Mining Tools from Tembelini, near Syama, Mali, West Africa, Mining History: Bull. Peak Dist. Mines Hist. Soc. 13 (6):6.

Lentin, A.G.L. 1800. Briefe über die Insel Anglesea. Siegfried Lebrecht Crusius, Leipzig.

Lewis, A. 1990. Underground exploration of the Great Orme Copper Mines. In Early Mining in the British Isles: The Proceedings of the Early Mining Workshop at Plas Tan y Bwlch, Snowdonia National Park Study Centre, edited by P. Crew and S. Crew, pp. 5-10. Plas Tan y Bwlch Occasional Paper 1.

- - - 1996. Prehistoric Mining at the Great Orme: Criteria for the identification of early mining. MPhil Thesis, University of Wales, Bangor.

O'Brien, W. 2004. Ross Island-Mining, Metal and Society in Early Ireland. Bronze Age Studies 6, National University of Ireland, Galway.

Pickin, J. 1990. Stone Tools and Early Metal Mining in England and Wales. In Early Mining in the British Isles: The Proceedings of the Early Mining Workshop at Plas Tan y Bwlch, Snowdonia National Park Study Centre, edited by P. Crew and S. Crew, pp. 39-42. Plas Tan y Bwlch Occasional Paper 1.

- - - 1999. Stone hammers from the Ecton Mines in the Bateman Collection, Sheffield, Mining History (Bulletin Peak District Mines Historical Society) 13 (5):15-18.

Pickin, J. and S. Timberlake. 1988. Stone hammers and firesetting: a preliminary experiment at Cwmystwyth Mine, Dyfed. Bulletin Peak District Mines Historical Society 10 (3):165-167.

Shennan, S. 1999. Cost, benefit and value in the organization of early European copper production. Antiquity 73:352-363.

Stanley, W.O. 1850. Note on Great Orme and Parys Mountain Copper Mines. Archaeological Journal 7:68-69. 
- - - 1873. Notes on vestiges of Roman workings for copper on Anglesey. Archaeological Journal 30:59-62.

Sykes, C. Sir. 1796. Journal of a Tour in Wales, National Library of Wales, Ms 2258C

Timberlake, S. 1990a. Excavations at Parys Mountain and Nantyreira. In Early Mining in the British Isles: The Proceedings of the Early Mining Workshop at Plas Tan y Bwlch, Snowdonia National Park Study Centre, edited by P. Crew and S. Crew, pp. 15-21. Plas Tan y Bwlch Occasional Paper 1.

- - - 1990b. Firesetting and primitive mining experiment, Cwmystwyth 1989. In Early Mining in the British Isles: The Proceedings of the Early Mining Workshop at Plas Tan y Bwlch, Snowdonia National Park Study Centre, edited by P. Crew and S. Crew, pp. 53-54. Plas Tan y Bwlch Occasional Paper 1.

-- - 2003. Excavations on Copa Hill, Cwmystwyth (19861999): An Early Bronze Age copper mine within the uplands of Central Wales, (British Series) 348. British Archaeological Reports, Archaeopress, Oxford.

- - - 2005a. Stone mining tools from Alderley Edge. In The Archaeology of Alderley Edge-Survey, Excavation and Experiment in an Ancient Mining Landscape, (British Series) No. 396, edited by S. Timberlake and J. Prag, pp. 58-78. British Archaeological Reports, Archaeopress, Oxford.

- - - 2005b. Experimental Mining on Alderley Edge. Part 1: A firesetting and mining experiment at Church Quarry in 1997. In The Archaeology of Alderley Edge-Survey, Excavation and Experiment in an Ancient Mining Landscape, (British Series) No. 396, edited by S. Timberlake and J. Prag, pp. 188-192. British Archaeological Reports, Archaeopress, Oxford.
- - - 2006. Excavations of early mineworkings at Twll y Mwyn (Cwm Darren) and Erglodd, Ceredigion. Archaeology in Wales 46:79-86.

- - - 2007. The use of experimental archaeology/archaeometallurgy for the understanding and reconstruction of Early Bronze Age mining and smelting technology. In Metals and Mines: Studies in Archaeometallurgy, edited by S. La Niece, D. Hook and P. Craddock, pp. 27-36. Archetype Publications/British Museum, London.

- - - 2009. Copper mining and metal production at the beginning of the British Bronze Age. In Bronze Age Connections-Cultural Contact in Prehistoric Europe, edited by P. Clark, pp. 94-121. Oxbow Books, Oxford and Oakville.

Timberlake, S. and B.R. Craddock 2005. Experimental Mining on Alderley Edge. Part 2: The manufacture of stone mining hammers-the record of a communal experiment on Alderley Edge. In The Archaeology of Alderley Edge-Survey, Excavation and Experiment in an Ancient Mining Landscape, (British Series) No. 396, edited by S. Timberlake and J. Prag, pp. 192-197. British Archaeological Reports, Archaeopress, Oxford.

Timberlake, S. and J. Prag 2005. The Archaeology of Alderley Edge-Survey, Excavation and Experiment in an Ancient Mining Landscape, British Series No. 396. British Archaeological Reports, Archaeopress, Oxford.

Worthington, T. and B. R. Craddock 1996. Modern Stone Tools. Mining History (Bulletin Peak District Mines Historical Society) 13 (1):58. 
Appendix 1. Standard record sheet for hammer stones.

\begin{tabular}{|c|c|c|c|}
\hline \multicolumn{3}{|c|}{ 1: IDENTITY } \\
\hline $\begin{array}{c}\text { Sample } \\
\text { No. }\end{array}$ & Year & Sector & Context $(\Delta)$ \\
\hline & & & \\
\hline
\end{tabular}

\begin{tabular}{|c|c|c|c|}
\hline \multicolumn{3}{|c|}{ 2: DIMENSIONS etc. } \\
\hline $\begin{array}{c}\text { Weight } \\
\text { (g) }\end{array}$ & $\begin{array}{c}\text { Length } x \\
\text { (cm) }\end{array}$ & $\begin{array}{c}\text { Width y } \\
\text { (cm) }\end{array}$ & $\begin{array}{c}\text { Depth z } \\
\text { (cm) }\end{array}$ \\
\hline & & & \\
\hline
\end{tabular}

\begin{tabular}{|c|c|c|c|c|c|}
\hline \multicolumn{6}{|c|}{ 3: SHAPE etc. } \\
\hline $\begin{array}{l}\text { Original } \\
\text { shape }\end{array}$ & $\begin{array}{l}\text { Natural } \\
\text { indentation }\end{array}$ & $\begin{array}{l}\text { Roundness } \\
\text { factor (1-9) }\end{array}$ & $\begin{array}{l}\text { Surface (1-4) } \\
\text { smoothness }\end{array}$ & $\begin{array}{l}\text { Natural/modern } \\
\text { abrasion }\end{array}$ & $\begin{array}{l}\text { Hardness } \\
\text { (3-8 mohs) }\end{array}$ \\
\hline Rectangular & & & Smooth (shore) & Glacial striae & 3 \\
\hline Spherical & & 6 & 1 & Beach attrition & 4 \\
\hline Ovoid & & 7 & 2 & Other & 5 \\
\hline Pear & & 8 & 3 & & 6 \\
\hline Cylindrical & & 9 & 4 & Modern & 7 \\
\hline Flattened & & & Rough & (accidental) & 8 \\
\hline
\end{tabular}

\section{4: PETROLOGY}

\begin{tabular}{|l|l|l|l|l|l|l|l|}
\hline & Grain size & Sorting & Banding & $\begin{array}{l}\text { Grain } \\
\text { roundness }\end{array}$ & $\begin{array}{l}\text { Fels. } \\
\%\end{array}$ & $\begin{array}{l}\text { Matrix } \\
\text { cement }\end{array}$ & Structure \\
\hline Siltstone & & & & 0 (angular) & & & \\
\hline Greywacke & Fine & V. well & & $1_{\text {i }}$ & $<2$ & & Joints \\
\hline Sandstone & Medium & Well & & 2 & $2-5$ & & Bedding \\
\hline Arkose & Coarse & Moderate & & 3 & $5-10$ & & Veins \\
\hline Quartzite & v. coarse & Poor & & 4 & $10-25$ & & Cleavage \\
\hline Other & Pebbly & & & 5 & $25-33$ & & Other \\
\hline & & & & 6 (spherical) & $33-50$ & & \\
\hline
\end{tabular}

\begin{tabular}{|c|c|c|}
\hline \multicolumn{3}{|c|}{ 5: COMPLETENESS } \\
\hline Small & $<25 \%$ & Unused \\
\hline \multirow{4}{*}{ Spall } & $25-40 \%$ & Pebble \\
\hline & $40-60 \%$ & \\
\hline & $60-75 \%$ & \\
\hline & $>75 \%$ & \\
\hline
\end{tabular}

\begin{tabular}{|c|c|}
\hline 6: TYPE & FRACTURE \\
\hline Conchoidal & Good \\
\hline & Medium \\
\hline & Poor \\
\hline Uneven & \\
\hline Planar & nature fracture) \\
\hline
\end{tabular}




\begin{tabular}{|c|c|c|c|c|c|c|c|}
\hline \multicolumn{8}{|c|}{ 7: WEAR ANALYSIS - 1 Hammering } \\
\hline \multicolumn{4}{|c|}{ End wear } & \multicolumn{2}{|c|}{ Edge wear } & \multicolumn{2}{|c|}{ Side wear } \\
\hline \multicolumn{2}{|c|}{ Single ended (1) } & \multicolumn{2}{|c|}{ Double ended (2) } & & \multirow[b]{2}{*}{ secondary } & \multirow[b]{2}{*}{ primary } & \multirow[b]{2}{*}{ secondary } \\
\hline Primary & secondary & Primary & secondary & Primary & & & \\
\hline Bruising & & & & Bruising & & $\begin{array}{l}\text { Slight } \\
\text { bruising }\end{array}$ & \\
\hline $\begin{array}{l}\text { Slight } \\
\text { pounding }\end{array}$ & & & & & & Bruising & \\
\hline $\begin{array}{l}\text { Moderate } \\
\text { pounding }\end{array}$ & & & & * & & Indentation & \\
\hline $\begin{array}{l}\text { Heavy } \\
\text { pounding } \\
\text { Flaking }\end{array}$ & & & & $\begin{array}{l}\text { Heavy } \\
\text { pounding }\end{array}$ & $\begin{array}{l}\text { Heavy } \\
\text { pounding }\end{array}$ & & \\
\hline $\begin{array}{l}\text { Heavy } \\
\text { flaking }\end{array}$ & & - & & & & & \\
\hline $\begin{array}{l}\text { Faceted } \\
\text { area }\end{array}$ & & & & $\begin{array}{l}\text { Faceted } \\
\text { area }\end{array}$ & & $\begin{array}{l}\text { Faceted } \\
\text { area }\end{array}$ & \\
\hline $\begin{array}{l}\text { Mineral } \\
\text { residue }\end{array}$ & & $\begin{array}{l}\text { Mineral } \\
\text { residue }\end{array}$ & & $\begin{array}{l}\text { Mineral } \\
\text { residue }\end{array}$ & & $\begin{array}{l}\text { Mineral } \\
\text { residue }\end{array}$ & \\
\hline
\end{tabular}

\begin{tabular}{|l|l|l|l|}
\hline 7.2 Grinding & \multicolumn{1}{|c|}{7.3 Crushing anvil use } & 7.4 Re-use as flake \\
\hline Location & Primary & Secondary & \\
\hline Faint & Slight bruising & & Hammering end \\
\hline & Strong bruising & & Chisel end \\
\hline Strong & Indentation & & \\
\hline & & & Degree of use \\
\hline Grinding marks - striations & Location & & Slight \\
\hline & Flake surface & & Moderate \\
\hline Faceted area/ & Pebble surface & Heavy \\
\hline & & & Scratch markings \\
\hline Mineral residue & Mineral residue & & \\
\hline
\end{tabular}

\begin{tabular}{|c|c|c|c|c|c|c|c|c|c|}
\hline \multicolumn{10}{|c|}{ 8: MODIFICATION (for hafting/handgrip) } \\
\hline Position & & Pri & ary & & Seco & dary & \multirow{5}{*}{$\begin{array}{l}\text { Use of } \\
\text { Natural } \\
\text { indentat- } \\
\text { ion in } \\
\text { Pebble }\end{array}$} & \multirow{3}{*}{$\begin{array}{l}\text { Contem- } \\
\text { porary } \\
\text { scratch/ } \\
\text { Scoring }\end{array}$} & \multirow{5}{*}{$\begin{array}{l}\text { Evidence } \\
\text { for haft } \\
\text { wear? }\end{array}$} \\
\hline mid girth & Edges & Side & $\begin{array}{l}\text { Semi- } \\
\text { continuous }\end{array}$ & groove & Edges & side & & & \\
\hline $\begin{array}{l}\text { Towards } \\
\text { narrow end }\end{array}$ & \multirow[t]{3}{*}{$\begin{array}{l}\text { Scratch } \\
\text { notching }\end{array}$} & & & & \multirow{2}{*}{$\begin{array}{l}\text { Rounded } \\
\text { sharp } \\
\text { edge of } \\
\text { Flake }\end{array}$} & & & & \\
\hline $\begin{array}{l}\text { Towards } \\
\text { broad end }\end{array}$ & & & & & & & & certain & \\
\hline $\begin{array}{l}\text { Centre of } \\
\text { gravity }\end{array}$ & & & & & Notching & & & Possible & \\
\hline
\end{tabular}

\begin{tabular}{|ll|}
\hline $\begin{array}{l}\text { 9: } \\
\text { SUMMARY DESCRIPTION OF TOOL } \\
\text { (Estimate) }\end{array}$ \\
\hline- & well used \\
- & poorly used \\
- & long survival of usefulness \\
\hline- & hammering \\
- & crushing \\
- & small hammer for other tool \\
- & anvil stone \\
\hline- & re-used \\
\hline- & recommend for detailed drawing \\
- & recommend retain collection \\
\hline
\end{tabular}

10: PHOTOGRAPHS

(3 views: digital or print)

11: DRAWINGS

(annotated field drawings with outline 1:1 profiles: longitud. and transverse) 
Appendix 2. Hammer-stone data record key.

COBBLE SHAPE: spherical $=1$; pear $=2$; ovoid $=3$; cylindrical $=4$; rectangular $=5$; flattened $=6$

COBBLE ROUNDNESS (1 to 9): factor 6 (slight irreg) - 9 (v round)

COBBLE SMOOTHNESS ( 1 to 6$)$ : 1 ( $v$ smooth $=$ beach pebble) -6 (rough)

SURFACE ABRASION: GS=glacial striae; $B A=$ beach attrition; $M=$ modern (accidental etc)

HARDNESS: Moh's hardness scale 2 (soft) $-8(v$ hard) NB vein quartz $=7-7.5$

PETROLOGY (rock type): $\mathrm{A}=$ mudstone/siltstone; $\mathrm{B}=$ laminated fine grained flaggy sandstone; $\mathrm{C}=$ fine grained felspathic grit/greywacke; $\mathrm{Ca}=$ more felspathic type; $\mathrm{Cc}=$ micaceous greywacke/bedded flagstone; $\mathrm{Cb}=$ quartzitic greywacke; $\mathrm{D}=$ quartzitic grit; $\mathrm{E}=$ quartzite; $\mathrm{F}=$ exotic(glacial erratic cobble - incl non-local quatzites and igneous rocks eg. dolerites, qtz porphyry)

Identified types of all cobbles include: Types $\mathrm{C}, \mathrm{Cb}, \mathrm{Cc}, \mathrm{Ca}, \mathrm{D}, \mathrm{Cc} / \mathrm{Cb}, \mathrm{Cb} / \mathrm{D}, \mathrm{Ca} / \mathrm{Cc}, \mathrm{Ca} / \mathrm{Cb}, \mathrm{Ca} / \mathrm{D}, \mathrm{Cc} / \mathrm{D}, \mathrm{A}, \mathrm{B}, \mathrm{E}, \mathrm{F}$

GRAIN SIZE (1-5): 1(Fine grained) - 5 (small pebbly clasts)

GRAIN ROUNDNESS FACTOR (1to 6): 1(angular) - 5 (nr spherical/well rounded grains)

FELDSPAR CONTENT: $\%$ of felspar from $<5 \%->75 \%$ (white grains of detrital plagioclase or orthoclase)

STRUCTURE: $\mathrm{J}=$ joints; $\mathrm{B}=$ bedding; $\mathrm{QV}=$ quartz vein; $\mathrm{CL}=$ cleavage

COMPLETENESS $=\%$ of cobble surviving, either as core or flake/spall

TYPE OF FRACTURE: $\mathrm{C}=$ conchoidal; $\mathrm{U}=$ uneven; $\mathrm{PL}=$ planar (usually premature fracture along joint plane or $\mathrm{qtz}$ vein

FRACTURE SCALE: 1=premature(planar)fracture; $2=$ uneven; $3=$ poor conchoidal; $4=$ medium conchoidal; $5=$ good conchoidal

WEAR ANALYSIS: END WEAR: x2=double ended; primary + 2ndry = use/re-use; 1=bruising; 2=slight pounding; 3 =moderate pounding; 4=heavy pounding; 5=flaking; 6=heavy flaking (similar scale with EDGE WEAR \& SIDE WEAR. FACET: $\mathrm{x} 1$ or $\mathrm{x} 2$ etc facets or surfaces worn flat from wear

CRUSHING ANVIL USE: flk= location on flake or fracture surface; pbl = location of use on natural pebble surface; $1=$ slight bruising; $2=$ strong bruising; $3=$ indentation

RE-USE AS FLAKE TOOL: $\mathrm{H}=$ hammering use; $\mathrm{CH}=$ chisel/pick use; $1=$ slight use; $2=$ moderate use; $3=$ heavy

MODIFICATION OF COBBLE (HAFTING): POSITION: $\mathrm{A}=$ mid-girth; $\mathrm{B}=$ towards narrow end; $\mathrm{C}=$ towards broad end; $\mathrm{D}=$ centre of gravity;

TYPE OF MODIFICATION: 1=scratch notching; $2=$ edge notches in cobble; $3=$ side notch/indentation; $4=$ semi-continuous groove; $\mathrm{A}=$ secondary notching of edges; $\mathrm{B}=$ rounded off sharp edges of flake; $\mathrm{C}=2$ ndry notching; $\mathrm{D}=2$ ndry side notch

HAMMER TYPE CLASSIFICATION: $\mathbf{1 A}=$ unmodified single end use as hammer; $\mathbf{1 A a}=$ double end use $(1$ end $>)$; $\mathbf{1 B}=$ use of side pebble as hammer for crushing/or as mallet; $\mathbf{1 C}=$ broken tip of hammer (or small pebble) re-used as hand-held crushing/pounding tool around edges; $\mathbf{1 D}=$ flake tool re-use (as chisel etc); $1 \mathrm{E}=$ use/re-use of cobble surface as anvil stone (for crushing); $\mathbf{1 F}=$ pecking stone for notching (typically lump quartz)

$\mathbf{2 A}=$ modified (notched for hafting) single end hammer; $\mathbf{2 A \mathbf { a }}=\ldots$...double end hammer;

$\mathbf{2 A E}=$ modified end hammer/anvil stone; $\mathbf{3 A}=$ further modified hammer( semi-grooved for hafting) ...etc 
Appendix 3. Krumbein's (1941) visual roundness chart for classifying original cobble shape (with EMRG Standard Record Sheet).

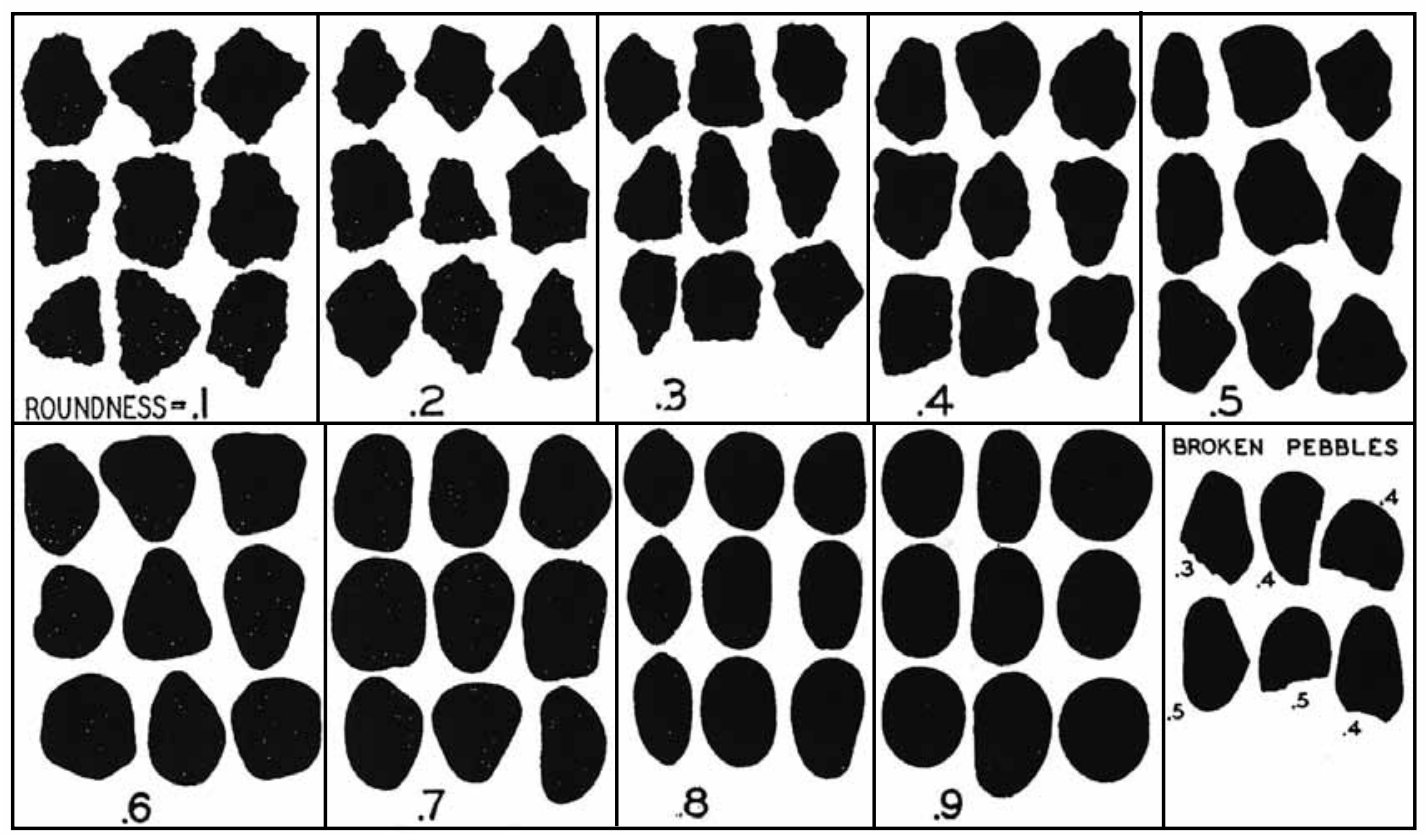


